Highlights

- Multi-proxy micro-geoarchaeological approach is suggested to study fire in tropical forests

- Hearths by immediate-return hunter-gatherers are ephemeral leaving a low signal

- Waste areas better preserve fire residues but in a secondary context

- Humid tropical environments are characterised by acidity and intensive biological activity

- In humid tropical environments charcoal and phytolith preserve better than ash and bone 


\title{
The formation of fire residues associated with hunter-gatherers in humid tropical environments: A geo-ethnoarchaeological perspective
}

David E. Friesem $^{a *}$, Noa Lavi ${ }^{b}$, Marco Madellac $^{c}$, Elisabetta Boaretto ${ }^{d}$, P. Ajithparsad ${ }^{\mathrm{e}}$, Charles French ${ }^{\mathrm{f}}$

\author{
${ }^{a}$ McDonald Institute for Archaeological Research, University of Cambridge, Cambridge, UK - df360@cam.ac.uk \\ bDepartment of Anthropology, University of Haifa, Haifa, Israel - noalaviw@gmail.com \\ ${ }^{3}$ ICREA, Department of Humanities, CaSEs Research Group, Universitat Pompeu Fabra and IMF-CSIC, \\ Barcelona, Spain - marco.madella@icrea.cat \\ ${ }^{4}$ D-REAMS Radiocarbon Dating Laboratory Scientific Archaeology Unit, Weizmann Institute of Science, \\ Rehovot, Israel - elisabetta.boaretto@weizmann.ac.il \\ ${ }^{5}$ Department of Archaeology and Ancient History, MS University of Baroda, Vadodara, Gujarat, India - \\ ajitkarolil@rediffmail.com \\ ${ }^{6}$ Department of Archaeology and Anthropology, University of Cambridge, Cambridge, UK - caif2@cam.ac.uk \\ ${ }^{*}$ Corresponding author - David Friesem (df360@cam.ac.uk)
}

\begin{abstract}
Tropical forests have been an important human habitat and played a significant role in early human dispersal and evolution. Likewise, the use of fire, besides being one of the exceptional characteristics of humans, serves as a marker for human evolution. While the use of fire by prehistoric hunter-gatherers is relatively well documented in arid and temperate environments, the archaeological evidence in humid tropical environment is to date very limited. We first review the archaeological evidence for hunter-gatherer use of fire in humid tropical environments and suggest that better understanding of formation processes is required. We present a geo-ethnoarchaeological study from South India, involving ethnography, excavations and laboratory-based analyses in order to build a new framework to study fire residues in humid tropical forests associated with hunter-gatherer's use of fire. Ethnographic observations point to a dynamic and ephemeral use of hearths. Hearths location were dictated by the social and ever-changing social dynamics of the site. The hearths deposited small amount of residues which were later swept on a daily basis, re-depositing ash and charcoal in waste areas and leaving only a microscopic signal in the original location. Particular acidic conditions and
\end{abstract}


intensive biological activity within tropical sediments result in the complete dissolution of ash and bones while favouring the preservation of charcoal and phytoliths. Consequently, the identification of fire residues in humid tropical forests and the reconstruction of the human use of fire must involve multi-proxy microscopic analysis to detect its micro-signatures.

Keywords: Pleistocene-Holocene; Geoarchaeology; Humid tropical environment; Site formation processes, Fire, Hunter-gatherers, 


\section{Introduction}

The use of fire is considered one of the exceptional characteristics of humans. The earliest evidence for the use of fire date back to over a million years ago (Bellomo 1994; Berna et al. 2012; Clark and Harris 1985) and unequivocal indication for habitual and controlled use of fire c. 300,000-400,000 BP (Bentesen 2014; Karkanas et al. 2007; Roebroeks and Villa 2011; Shimelmitz et al. 2014). The use of fire played a major role in the evolution and development of complex and advanced behaviour of humans (e.g., Brown et al. 2009; Goren-Inbar et al. 2004; Roebroeks and Villa 2011). Therefore, the study of prehistoric use of fire bears significant implications for research concerning the human past. In order to allow the reliable interpretation of early use fire and reconstruct human pyrogenic behavior, one must carefully examine the archaeological context and study the formation processes of fire residues (Goldberg et al. 2017; Mallol et al. 2017; Mentzer 2014).

Studying site formation processes is especially crucial when examining the role tropical environments play as a human habitat during prehistoric times (Mercader 2003a; Morley and Goldberg 2017), and in particular in the dispersal of humans into South and Southeast Asia (Barker 2013; Barker et al. 2007; Gosden 2010; Morley 2017; Perera 2010; Roberts and Petraglia 2015; Roberts et al. 2015; Summerhayes et al. 2010). The case of the 'simple' lithic industry abundant in Southeast Asia during the Late Pleistocene had been argued to not be interpreted as a mere reflection of a rather 'simple' behaviour but that a rich and complementary industry was made of degradable plant materials (also termed 'the Bamboo Theory', see Bar-Yosef et al. 2012; Boriskovsky 1967; Brumm 2010; Gorman 1969, 1971; Hutterer 1976; Lycett and Bae 2010; Pope 1989; Reynolds 2007; Solheim 1972; White 1977; Xhauflair 2012, 2016). The 'bamboo theory' is based on the assumption that due to the environmental conditions in Southeast Asia and taphonomic processes in humid tropical environments, plant material will not preserve in the archaeological record. Similarly, the scarce archaeological evidence for use of fire in humid tropical forests raise a similar question - whether it is an absence of evidence or an evidence of absence. To date, geoarchaeological studies aiming to understand the formation processes of combustion features largely concentrated on temperate, semi-arid and arid environments (Goldberg and Macphail 2006; Mentzer 2014 and references therein) compared to the humid tropics (Mercader 2003a; Morley and Goldberg 2017). 


\section{Archaeological evidence of hunter-gatherer use of fire in humid tropical environments}

Early human occupation of humid tropical environment is suggested to date back 200,000 years (Mercader 2002, 2003a). However, direct evidence for human adaptation and long-term occupation of tropical forests emerge around 45,000 BP (Roberts and Petraglia 2015; Roberts et al. 2015). To date, the earliest evidence for fire residues associated with human activity in humid tropical environment was reported from the Niah Caves, Sarawak, Borneo dating to around 45,000 BP (Lewis 2016; Stephens et al. 2005, 2017). Fire residues dated between $\mathrm{c}$. 20,000-30,000 BP were also reported in other sites in Southeast Asia such as Tham Lang Rongrien (Anderson 1997) and Tràng An (Rabett et al. 2011, 2017) both in Thailand, Tabon Cave in Palawan, Philippines (Lewis 2007) and Liang Bua in Flores, Indonesia (Morley et al. 2017). In Africa, charcoal found alongside Late Stone Age lithic in Njuinye, Cameroon, was dated to c. 35,000 BP (Mercader and Marti 2003). Similar radiocarbon dates were yielded from charcoal reported from layers of 'stone-lines' in Mosumu, Equatorial Guinea, dating back to c. 30,000 BP (Mercader et al. 2002). In South America, evidence of archaeological fire residues were found among the earliest sites of human occupation in humid tropical environment during the Pleistocene-Holocene transition around 12,000 BP (Gnecco and Mora 1997; Roosvelt et al. 1996; Villagran et al. 2017).

Geoarchaeology is commonly used to directly associate the presence of fire residues with past human behaviour, as it allows a microscopic investigation of the formation and deposition processes of the residues (Goldberg et al. 2017; Mentzer 2014). While microgeoarchaeology had become the most common approach to study Palaeolithic fire worldwide (Goldberg et al. 2017), only few geoarchaeological studies were implemented in humid tropical environments (Morley and Goldberg 2017). Few of them studied fire residues that could be directly associate with hunter gatherer occupation in South and Southeast Asia (Anderson 1997; Gillieson and Mountain 1983; Kourampas et al. 2008, 2009; Lewis 2007; Magee 1988; Mijares and Lewis 2009; Morley et al. 2017; Rabett et al. 2011; Simpson et al. 2008; Stephens et al. 2005, 2017), Africa (Mercader et al. 2003b) and South America (Araujo et al. 2008; Villagran et al. 2017). The most abundant form of fire residue in humid tropical sites appears in the form of charcoal (e.g., Aceituno et al. 2012; Anderson 1997; Araujo et al. 
2008; Gillieson and Mountain 1983; Gnecco and Mora 1997; Kourampas et al. 2008, 2009; Lewis 2007, 2016; Magee 1988; Mercader 2003a; Mercader et al. 2003b; Mijares and Lewis 2009; Morley et al. 2017; Rabett et al. 2011; Roosvelt et al. 1996; Simpson et al. 2008; Stephens et al. 2005, 2017; Villagran et al. 2017). However, the presence of charcoal alone can also derived from natural fire (e.g., Summerhayes et al. 2017). Additional human-related fire residues abundant in archaeological sites around the world include wood ash particles, rubified clay aggregates, fire-related clasts and burnt bones and shells (Mentzer 2014). The major challenge imposed on the preservation of fire residues in humid tropical environments lays in the acidic conditions of humid tropical soils. Under these conditions carbonates tend to dissolve which archaeologically result in absence of wood ash (calcite), bone (carbonated hydroxyapatite) and shells (aragonite and/or calcite) (Friesem et al. 2016). On the other hand, wood charcoal (structure resembling graphite) and phytoliths (opal) tend to preserve under acidic conditions (Friesem et al. 2016). Consequently, the majority of the archaeological sites where wood ash and burnt bone were preserved are situated on limestone or within karstic systems (Anderson 1997; Araujo et al. 2008; Gillieson and Mountain 1983; Lewis 2007, 2016; Magee 1988; Mijares and Lewis 2009; Morley et al. 2017; Rabett et al. 2011; Stephens et al. 2005, 2017; Villagran et al. 2017). The carbonate-rich environment act as a buffer and prevent the reduction in $\mathrm{pH}$ levels that allows better preservation of wood ash and bones (Weiner 2010). Only a handful of studies reported on preservation of intact hearths that can be clearly associated with in situ use of fire (Anderson 1997; Morley et al. 2017; Villagran et al. 2017). Yet, several others had suggested that the presence of wood ash, charcoal, burnt bone and burnt soil substrate and/or clay aggregates, even if reworked and/or disturbed, should be interpreted as reworking of adjacent combustion features, either as a result of post-depositional disturbance or as rake-out and dumping activity (Araujo et al. 2008; Kourampas et al. 2009; Lewis 2007, 2016; Mercader 2003b; Mijares and Lewis 2009; Rabett et al. 2011; Simpson et al. 2008; Stephens et al. 2017). More than reflecting the entire range of human behaviour, the archaeological record of human use of fire reflects the taphonomic conditions and state of preservation of fire residues (Mentzer 2014). For this reason, most of the studies that identified Palaeolithic fire residues took place in caves and rock-shelters (Goldberg et al. 2017) as opposed to open-air sites (e.g., Friesem et al. 2014b). This situation is enhanced in humid tropical environments where very few studies reported fire residues in open-air sites associated 
with hunter-gatherers occupation (e.g., Gnecco and Mora 1997; Simpson et al. 2008). It was suggested that Pleistocene hunter-gatherers did not use rock-shelters, and perhaps also caves, as long-term dwelling sites, but used them only intermittently as brief campsites (Anderson 1997; Mercader 2003a).

In contrast to the archaeological image, ethnographic data from contemporary huntergatherers living in humid tropical environments suggest that most of their habitation sites and activity take place in open-air sites with routine use of fire (e.g, Bird-David 2009, 2017; Endicott 1979; Fisher and Strickland 1989; Gardner 2000; Hewlett 1993; Morris 1982; Turnbull 1965 to mention but a few). Although, the analogy between contemporary huntergatherers and Pleistocene ones is problematic, to say the least (see below on ethnoarchaeology), the ethnographic data raise an important archaeological question; how can we improve the identification and interpretation of fire residues in humid tropical environments to allow better reconstruction of human behaviour in this important habitat?. The first step in this pursuit should therefore be to gain better understanding of the processes that form the insubstantial archaeological record of fire residues in humid tropical environments. To do so, we must address the two major factors in archaeological site formation processes; (1) the human factor (e.g., how people used fire, maintained it, discard it, etc.), and (2) the natural taphonomic processes affecting the preservation and deposition of fire residues (ShahackGross 2017).

\section{Materials and methods}

\subsection{Aim and the geo-ethnoarchaeological method}

The aim of this study was to understand how hunter-gatherer activity and environmental processes in humid tropical forests affect the formation and preservation of fire residues. In order to properly clarify the entire sequence of processes involved in the formation of the archaeological evidence, from the human activity that initially deposits the residue(s) to the post-depositional taphonomic processes, we present a geo-ethnoarchaeological case study (see Friesem 2016 for a review on geo-ethnoarchaeology). First, ethnoarchaeological observations provide understanding about how human activity is directly associated with specific patterns

of deposition (David and Kramer 2001). This is not to imply that contemporary hunter-gatherer societies reflect past societies, rather that current context can provide an experimental setting 
to observe the dynamics of how distinct human activities result in specific patterns of material deposition (e.g., Friesem and Lavi 2017). The integration of geoarchaeological analyses add invaluable information regarding the formation of proxy signatures related to the dynamics, and therefore to the documented activity (Mallol and Henry 2017). The geoethnoarchaeological approach involves the excavation, sampling and analysis of in use or recently abandoned settlements (Friesem 2016). The recently abandoned settlements allow for a "near-archaeological" setting with two main advantages:

1) Having being abandoned in the recent past the history of activities and abandonment are well documented by living informants.

2) Post-depositional processes already started to influence the deposit(s).

The case study presented here forms a part of a larger project (TropicMicroArch) which involved: 1) a long-term ethnographic work among the Nayaka, a contemporary group of hunter-gatherers living in the forested hills of the Western Ghats in Tamil-Nadu in India (Figure 1);2) excavations of open-air sites and a rock-shelter abandoned by the same group of people c. 30 years ago; 3) geoarchaeological analysis of sediment samples and radiocarbon dating of charcoal from the contemporary site and the excavated abandoned site; and 4) the construction of a methodological framework to study hunter-gatherers in open-air sites in humid tropical environments.

\subsection{Sampling and laboratory analysis}

Sediment samples were collected from three different locations: 1) the exterior activity terrace of the current settlement; 2) an abandoned near-by open-air site (from the terrace and the slope over the edge of the terrace); and 3) an abandoned rock-shelter. Similar analytical proxies were applied to all the contexts. These included Fourier-Transform Infrared (FTIR) spectroscopy, phytolith quantification, Inductively Coupled Plasma-Atomic Emission Spectroscopy (ICPAES), soil micromorphology and Accelerator Mass Spectrometry (AMS) radiocarbon dating based on calibrated ${ }^{14} \mathrm{C}$ age. A comparison made between the findings in the different sites illustrates the post-depositional processes, the potential of preservation and the archaeological formation of a fire signature in humid tropical environment. For the full report of the ethnoarchaeological fieldwork and laboratory analysis see Friesem and Lavi (2017) and Friesem et al. (2016). 


\section{Ethnoarchaeological observations on hearths}

Ethnographic observations among the Nayaka highlighted the major role fire plays in their social and economic practices. Fire is used for roasting and cooking food as well as for heating, to protect the settlement from wild animals and as a hub for social interaction. Regardless of the type of activities carried out around the fire, the hearths were built, maintained and discarded in a similar way (Figure 2). Living in steep forest hills, Nayaka houses are built on large terraces built by excavating into the hill slope and removing the soil to create a platform (Friesem and Lavi 2017; Friesem et al. 2016). All Nayaka activities, except for sleeping, take place on the terrace outside their houses (see Bird-David 2009, 2017; Friesem and Lavi 2017 for more information on Nayaka use of space, daily activity and its social reasoning. But see also Bird-David 2017 who showed that in the 1970s sleeping was often done outside on the terrace as well).

Hearths are also always placed on the terraces, outdoor. Each time someone comes back to the site s/he would carry a small pile of branches and twigs, and occasionally a few large logs, to be used as firewood. No special structure is built to accommodate the hearth and a fire is started by using thin branches laid down directly on the terrace and lit to create a fireplace normally of less than $1 \mathrm{~m}$ in diameter (Figure 2a). Every now and then someone would add a new branch from an adjacent pile of firewood to keep the fire going. Generally, the fires are slow burning and left to die during the night as no one attends them (Figure $2 \mathrm{~b}$ ). Occasionally, if people wake up in the middle of the night, they would warm near the fire, allowing them to remain active in the morning. Only in cases of immediate threat from an approaching wild animal (e.g., elephant, bear or tiger) a large fire would be produced to scare the animal away, but this was rarely the case during our observations.

Being fueled by a relatively small amount of firewood and kept slow burning, the hearths deposits consisted of small piles of ash, some wood charcoals and pieces of partly burnt wood (Figure 2b). Sweeping and cleaning of the terrace surface, and in particular sweeping the hearths, was carried out daily using a broom made of thin twigs (Figure 2c). The practice of sweeping floors among hunter-gatherers was reported by several ethnoarchaeologists (see Friesem and Lavi 2017 for the Nayaka; see Fisher and Strickland 1989 for the Efe in Zaire; see O'Connell 1987 for the Alyawara in Australia; see O'Connell et al. 1991 for the Hadza in 
Tanzania). This routine practice bears significant archaeological implications for the preservation of in situ residues of occupation deposits (Friesem and Lavi 2017; Friesem et al. 2016; Milek 2012). After sweeping, only a very thin layer of ash remained in the original location of the hearth (Figure 2c). The large charcoal pieces are moved and re-deposited over the edge of the terrace along the slope, forming a waste (midden) area together with other residues (Friesem and Lavi 2017; for ethnoarchaeological examples for the formation of similar waste areas in hunter-gatherers sites see Binford 1978 for the Nunamiut in Alaska; see Fisher and Strickland 1989 for the Efe in Zaire; see Gargett and Hayden 1991 for the Pintupi in Australia; see O'Connell 1987 for the Alyawara in Australia; see O'Connell et al. 1991 for the Hadza in Tanzania). Because of these maintenance practices, hearths were very rarely refire in the exact same location (Figure 2d). The Nayaka hearths are very much ephemeral and part of the terrace living dynamics in an ever-changing pattern (see Friesem and Lavi 2017 among the Nayaka; and for other hunter-gatherer groups see Fisher and Strickland 1989 for the Efe in Zaire; O'Connell 1987 for the Alyawara in Australia; O'Connell et al. 1991 for the Hadza in Tanzania).

The social dynamics among the Nayaka are dictated by immediacy and mobility (BirdDavid 1994, 1999), as is the case for many other hunter-gatherers defined as immediate-return groups (Woodburn 1982). Immediacy among the Nayaka is reflected by the immediate ad hoc social interaction, relationships and knowledge (Bird-David 1994, 1999) and a dynamic use of space where activity areas are formed according to immediate social and/or functional needs (Friesem and Lavi 2017). Among the Nayaka, mobility is not only expressed through the shift of an entire habitation site or of people between sites, but also, and more frequently, by the ceaseless change of locations for the activity areas within a site to allow an individual to constantly share with her/his relatives things, actions and spaces (see Bird-David 2009; Lavi and Bird-David 2014 for the Nayaka; and for other hunter-gatherer groups see Briggs 1970 for the Autako in Northern America; see Hewlett et al. 1982; Turnbull 1965; Woodburn 1968, 1972; for the Aka, Mabuti and Hadza respectively in Africa; see Jackson 1995; Myers 1986; for the Pintupi and Walpiri respectively in Australia). A typical hearth in the observed settlement was used in the same place for a short period of time, usually for a maximum of 24 hours, and the next morning would be cleared and swept (Figure 2c). The location of hearths is therefore based on the "now-and-then" presence of people and the impromptu relationships 
between them (Friesem and Lavi 2017). The composition and locations of people at the site are constantly changing and, as a result, the hearths are used where people gather, eat and sleep at a given moment or due to changes in rain and wind. No designated locus exists for where to set a hearth and no fire is active at the same location for a long period of time (less than 24 hours).

In most cases on the next morning, sweeping left only an obscured patch of ash in the location of the hearth (Figure 2c-d). During the monsoon season, the heavy rain wash away all the ash remains leaving no fire residues visible to the naked eye (Figure 3 - day 2). When several hearths are used in relative proximity, a thin grey layer of ash can be observed even few days after abandonment (Figure 3 - day 8). Overall, after a week from abandoning a hearth, no visible traces of fire residues can be observed by the naked eye on the terrace surface. The sediment of the terrace surface below the ash did not show any significant colour change (Figure 4b-c). Since the sediments and soils in the area are rich in iron the identification of reddening due to exposure to high temperatures of the already red-coloured sediment was very difficult. The excavations of the abandoned sites showed no macroscopic artefacts or any visible traces for human activity except for house debris in the open-air sites (Figure 4d-e). Two exceptional localities exhibited charcoal remains visible during excavation: 1) Small charcoal fragments were found within the sediment in the slope of the open-air site in the area interpreted as the waste area (Figure 4f) and 2) a thin charcoal horizon was found in one trench of the rock-shelter (Figure 4g, i).

\section{Results and discussion}

\subsection{Geoarchaeological analysis of fire residues}

Infrared analysis of the sediments showed clay (kaolinite) to be the main mineralogical component (Friesem et al. 2016). Most of the sediments did not show any indications for alteration of the clay mineral due to exposure to high temperature (Figure 5a). No evidence for clay pyrogenic alteration was observed even in the millimeter thick grey ashy layer sampled from the surface of the contemporary terrace where a hearth was just recently abandoned (Figure 4b). However, this sample was the only one to show high amounts of calcite due to the presence of wood ash (Figure 5b). The samples from the open-air abandoned site (Figure 5c) were very similar to the regional sediment controls and to the surface of the contemporary 
terrace, with no evidence for wood ash (calcite) or alteration of clay due to high temperature. The sediment sample collected from the charcoal horizon (Figure 5d) also did not contain calcite, but its clay component showed signs that can be interpreted as minor kaolinite alteration due to exposure to temperatures higher than $400^{\circ} \mathrm{C}$ but probably lower than $600^{\circ} \mathrm{C}$ (Friesem et al. 2014a).

The results of phytolith quantification are presented in figure 6. Quantification of phytolith from the control regional sediment presented a range of 0.25 to 0.5 million phytoltihs in 1 gram of sediment [henceforth $\mathrm{M} \mathrm{p} / \mathrm{gr}$ ]. Phytolith concentrations within most of the terrace sediments range between 0.25 to $1 \mathrm{M} \mathrm{p} / \mathrm{gr}$. The ashy sample from the recently abandoned hearth had $2.3 \mathrm{M} \mathrm{p} / \mathrm{gr}$. From the abandoned open-air site samples only one from the middle of the terrace trench profile (Figure $4 \mathrm{e}$ ) yielded concentration above $1 \mathrm{M} \mathrm{p} / \mathrm{gr}$. Lacking other lines of evidence it is not clear whether this concentration of phytoliths originated from activity associated with burnt plants or other uses of unburnt plants. Phytolith concentrations in the slope deposits were not significantly higher than in the regional control samples (Figure 6). Sediments collected from the upper part of the profile where the charcoal horizon was found in the rock-shelter (Figure 4g) exhibited very high concentrations of phytoliths with between $2-4 \mathrm{M} \mathrm{p} / \mathrm{gr}$, significantly higher than the ash layer in the contemporary site.

The elemental analysis of the samples described above showed that the ashy sample from the current settlement consisted of high concentrations of phosphorus $[\mathrm{P}]$, calcium $[\mathrm{Ca}]$, potassium $[\mathrm{K}]$, magnesium $[\mathrm{Mg}]$ and strontium $[\mathrm{Sr}]$ (Figure 7). Previous geoethnoarchaeological studies suggested that elevated concentrations of this set of elements in sediments can be associated with use of fire (e.g., Middleton and Price 1996; Rondelli et al. 2014; Wilson et al. 2008). The samples surrounding the recently abandoned hearth in the contemporary terrace showed lower amounts of this set of elements which further support their association with hearth remains (Rondelli et al. 2014). Only K was relatively higher across the contemporary terrace in comparison to the sediments from the abandoned sites, indicating the leaching out of $\mathrm{K}$ after abandonment. The samples collected from the open-air site and its slope did not show significant higher presence of the above elements indicating the poor preservation of anthropogenic chemical signature. The difference between the samples in the abandoned open-air site are negligible. The samples from the profile in the abandoned rock-shelter exhibited elevated concentrations of $\mathrm{P}$ and $\mathrm{Mg}$, similar to the ashy layer of the recently 
abandoned hearth in the contemporary site but significantly lower amounts of $\mathrm{Ca}$, Sr. Closer examination of the samples and their location in relation to the charcoal horizon, located in the middle layer of the profile, reveals that $\mathrm{P}$ and $\mathrm{Mg}$ were lower in the middle layer and higher above the charcoal horizon, while $\mathrm{Ca}$ and $\mathrm{Sr}$ were higher in the charcoal horizon. The latter are associated with the presence of ash (e.g., Middleton and Price 1996; Rondelli et al. 2014; Wilson et al. 2008), thus indicated that the charcoal horizon was overlain by organic matter (with elevated P, Mg and phytoliths) which is not associated with fire residues.

Micromorphological analysis of undisturbed sediment blocks was carried out on samples from the abandoned open-air site and rock-shelter. Overall, observations under the microscope revealed the extensive disturbance of the sedimentary sequence due to intensive bioturbation (plant roots, insects, rodents, birds and reptiles) (Figure 8a). The sample from the open-air site terrace trench shows a crumbly and disturbed structure, which does not allow unequivocal identification of activity surfaces, while the sample from the slope showed the presence of micro-charcoal and indications of secondary deposition characteristic of waste areas where fire residues have been discarded (Figure 8b). In addition, some of the charcoal showed signs of chemical deterioration due to the acidic conditions, but not mechanical decay (Figure 8c). No bone fragments or ash particles were identified in any of the samples from the abandoned sites. The block sediment sample from the rock-shelter showed a less disturbed micro-stratigraphic sequence with a well-preserved charcoal horizon buried under postabandonment sediment (Figure 8d). In the middle of the post-abandonment sediment a rich organic layer was observed. By combining the information from the elder Nayaka informants and the geochemical analysis (see above), this layer was interpreted as a post-abandonment deposition of a collapsed lean-to thatched roof, known to be used in this locality. In general, the micromorphology analysis was able to identify fire occurrence only via the presence of micro-charcoal. The deposition patterns observed under the microscope enabled to interpret the charcoal horizon in the rock-shelter as an in situ hearth and the charcoal fragments in the slope of the open-air site as a waste area. The sediments in the rock-shelter, being protected from the rain and wind, presented better preservation than the open-air site (see Mallol et al. 2007 for the effect of wind and rain on poor preservation of fire residues in open-air sites).

\subsection{Radiocarbon dating of fire residues}


Five charcoal samples discovered during the excavations of the abandoned open air site $(n=2)$ and rock-shelter $(\mathrm{n}=3)$ and one charcoal sample collected from the contemporary site, were AMS dated based on calibrated ${ }^{14} \mathrm{C}$ age. Results of the radiocarbon dating of the charcoal samples are presented in Table 1. The ethnographic observations made clear that charcoal residues can result from the burning of twigs as well as relatively large branches and logs (Figure 2). This of course calls for caution as the results might be affected by the old wood affect (i.e., dating the part of the tree which is part of old rings formed many years before the actual use of the wood by the people). Observations made on the charcoal samples before dating could not clearly trace rings in order to estimate the type of wood (e.g., twig/small branch or a $\log$ ). A charcoal sample (TM 110) from the surface of contemporary site (Figure 4a) is dated to early 2000s AD. This sample was collected in $2015 \mathrm{AD}$ and the ethnographic information we gathered and our own observations suggest that the Nayaka do not tend to use very large logs. Two charcoal samples from the slope of the open-air site (Figure 4f) indicate inverted stratigraphy with the sample from the lower part (TM 41) younger than the one from the middle part (TM 37) of the slope section. Our ethnographic data do not support maintenance of waste areas or other form of human activities that will result in mixing of the midden's deposits. However, micromorphological analysis evince biological activity (e.g., rodents, insects, roots, etc.) within the sediments resulting in intensive bioturbation (Figure $4 \mathrm{~b})$. Yet, the dates indicate the presence of the Nayaka at this location from at least the first half of the $20^{\text {th }}$ century. One sample (TM 88) from the rock-shelter has an age of late 1970s AD. The other two samples (TM 95 and 100) from the rock-shelter come from two locations along the same charcoal horizon (Figure $4 \mathrm{~g}$ and $\mathrm{i}$ ) and their radiocarbon dates are very similar. The relatively early dates of these samples might be due to the use of old wood as the micromorphology analysis highlighted the presence of large charcoal pieces (Figure 8d). Indeed, our informants confirmed that the rock-shelter appears to have been already in use during the second half of the $20^{\text {th }}$ century.

\section{Anthropogenic and taphonomic formation processes}

The formation processes related to fire residues in this study can be divided into two categories: 1) processes associated with human activity and 2) processes associated with the humid tropical forest environment (Table 2). Social norms and behaviour among immediate-return 
contemporary hunter-gatherers (immediacy, mobility and sharing) result in a dynamic and ephemeral nature of fireplaces used in the sites (see also Friesem and Lavi 2017). The lack of constructed or conditioned structures to accommodate the fire, the short duration of each fire episode in a specific locality, and the practice of a slow-burning fire, result in the deposition of very small quantities of ash, charcoal and unburnt wood and little or no thermal alterations. The ephemeral nature of these combustion features and the low archaeological signal they generate has been already called to attention by several ethnoarchaeological studies (e.g., Fisher and Strickland 1989 for the Efe in Zaire; Mallol et al. 2007; O'Connell et al. 1991 for the Hadza in Tanzania; O'Connell 1987 for the Alyawara in Australia). The few studies to report intact in situ hearths in prehistoric sites in humid tropical environment based their interpretation on identification of burnt earth substrate overlain by a dark organic layer (e.g., charcoal) and an ashy layer deposited at the top of the combustion feature (Anderson 1997; Morley et al. 2017; Villagran et al. 2017). This structure correlate well with an open fireplace as described by this study and Mallol et al. (2007) who performed a geo-ethnoarchaeological study of hunter-gatherer hearths among the Hadza in Tanzania.

The daily routine of clearing hearths and sweeping the floors removes all the macroscopic as well as a significant part of the microscopic residues. This practice is actually the principal process influencing the preservation of fire residues in their primary context. The act of sweeping clears the primary activity area of most residues and re-deposits them in middens. In our case the waste area is found on the slope, over the edge of the exterior terrace. Once in their secondary context, fire residues seems to better preserve than the few residues left in the primary activity area. From our observations in the field and analysis, it is clear that a rapid burial is key for the preservation of fire residues (see also Friesem et al. 2014b for discussion on wood ash preservation as directly associated with rapid burial), in particular in hunter-gatherer sites in humid tropical environments. The charcoal horizon we identified in the rock-shelter presents an exceptional case of an in situ combustion feature, but one that probably was left behind when the rock-shelter was abandoned and represent the very last activity before abandonment. As a consequence, in situ hearths should be carefully interpreted as they often may represent only the last fire event before an abandonment episode. On the other hand, fire residues preservation is higher in middens, especially during the settlement life, due to higher rate of accumulation and rapid burial. 
Among the many post-depositional processes active in humid tropical forests, intensive biological activity in the sediments poses a real challenge to the stratigraphic preservation of combustion features. Smaller material can be transported along the sequence and new material can also be incorporated (Madella and Lancelotti 2012), and carbonates are quickly dissolved due to the humid and generally acidic depositional environment typical of humid tropical forests. Therefore, wood ash and burnt bones, which often characterize prehistoric fire structures (Goldberg et al. 2017; Mallol et al. 2017; Mentzer 2014), will quickly dissolve soon after deposition. Fortunately, phytoliths and charcoal tend to preserve better under acidic conditions. It should be noted that preservation of ash and bones in humid tropical forests is common in sites located within a carbonate-rich depositional environment (e.g., on limestone or in karstic systems), where the carbonates from the rock will act as a buffer (e.g., Anderson 1997; Araujo et al. 2008; Gillieson and Mountain 1983; Lewis 2007, 2016; Magee 1988; Mijares and Lewis 2009; Morley et al. 2017; Rabett et al. 2011; Stephens et al. 2005, 2017; Villagran et al. 2017). Our study shows that while the small branches and twigs were burnt completely leaving only ash, the large branches and logs left behind larger pieces of charcoal that preserved better and which were therefore more identifiable after abandonment. In terms of archaeological preservation, our results show that the relative low amount of logs and large branches produced a more noticeable signature than the more frequently used short-lived firewood.

Based on our case study and previous geoarchaeological studies, we conclude that the relative absence of clear fire residues in prehistoric archaeological sites located in the humid tropics, compared to other parts of the world, is related to; (1) hunter-gatherer use of fire that probably result in small-scale and short-lived fireplaces, (2) site maintenance that routinely cleared out fire residues from their primary context, (3) taphonomical processes due to intensive biological activity within the sediments and acidic conditions, and (4) lack of rigorous geoarchaeological investigation that will apply a multi-proxy approach. While the first three factors are an integrated part of archaeological site formation processes in humid tropical environments, the last one is now changing and will probably bring new information on the use of fire among hunter-gatherers in humid tropical forests (Morley and Goldberg 2017) 


\section{Identification of fire residues in humid tropical forests}

This study show how the way Nayaka use fire and the taphonomical processes in humid tropical environments do not favour a good preservation of fire remains. Yet, some remains could still be traced in the abandoned sites. The geo-ethnoarchaeological approach, where different geoarchaeological methods were supported by ethnographic observations, has given a better understanding of the formation processes of fire remains and also provided an interpretative framework for the investigation of these remains in tropical forests (Table 3).

The reality of archaeology in humid tropical forests shows that the environmental conditions hampers the preservation of intact combustion features, as also demonstrated from our case study. Nevertheless, fire residues were more likely to preserve in the waste areas, although in secondary context, the identification and investigation of discarded fire residues is significant for reconstructing human behaviour and use of fire at the site. It is therefore of particular importance to differentiate between the primary context of an in situ hearth for example, and secondary context of where fire residues are dumped. The routine approach to study combustion features generally relies on micromorphology and the investigation of the micro-context (Goldberg et al. 2017; Mallol et al. 2017; Mentzer 2014). In few cases geoarchaeological studies successfully identified in situ combustion features in humid tropical sites. Anderson (1997) described ephemeral and localized hearths found in Tham Lang Rongrien, Thailand, associated with Pleistocene layers dated between 27,000 and more than 43,000 B.P. The hearths were about $1 \mathrm{~m}$ in diameter, identified by the presence of charcoal, ash, and fire-reddened sand with only a couple been partially stone-lined. More recently, Morley et al. (2017) identified an in situ hearth with intact and well-defined structure showing a reddened substrate overlain by a dark organic-rich layer and an upper calcareous ash layer. This hearth, found within layers dated between 41,000 and 24,000 BP in Liang Bua Cave in Flores, Indonesia, exhibit a similar structure of an open fireplace fuelled by relatively low amount of wood. Villagran et al. (2017) identified similar context interpreted as open fireplaces that left a burnt soil substrate overlain by wood ash in Lapa do Santo rock-shelter in eastcentral Brazil, where an early Holocene settlement was dated to 7,900-12,700 BP. In contrast, it has been more common to interpret the presence of fire residues in humid tropical sites as representing reworked areas resulting from rake-out (e.g., Araujo et al. 2008; Kourampas et al. 2009; Lewis 2007, 2016; Mercader 2003b; Mijares and Lewis 2009; Rabett et al. 2011; 
Simpson et al. 2008; Stephens et al. 2017). However, due to post-depositional processes such as biological activity within the sediments, deterioration of organic matter and dissolution of ash, the primary context of in situ combustion features can be disturbed and thus challenging for interpretation. Villagran et al. (2017) applied a multi-proxy geoarchaeological methodology, using micromorphology, organic petrology and FTIR, in order to distinguish between intact hearths and remobilized combustion debris, possibly hearth rake-out. By performing heating experiments on the local soil and measuring them with $\mu$ FTIR they were able to detect burnt soil substrate in cases where micromorphological observations alone failed to identify clear evidence for burning.

We conclude that in order to overcome the challenge of fire residues preservation in the humid tropics, a multi-proxy approach is indispensable. Mineralogical analysis (using FTIR) can provide indications for use of fire (e.g., alteration of clay due to exposure to high temperatures)(Forget et al. 2015; Villagran et al. 2017) even where no other direct residues preserve (e.g., charcoal, ash and phytoliths). Elemental analysis showed that combustion features result in elevated concentrations of $\mathrm{P}, \mathrm{Ca}, \mathrm{K}, \mathrm{Mg}$, and Sr. After abandonment, postdepositional processes result in leaching out of $\mathrm{Ca}, \mathrm{K}$ and $\mathrm{Sr}$ (leaching of $\mathrm{Ca}$ will be reduced in karstic setting). Although P and Mg tend to better preserve, they can also be associated with deposition of unburnt organic matter and cannot exclusively be interpreted as indicative of a fire signature. The relatively good preservation of charcoal and phytoliths in humid tropical environments makes them a reliable proxy for identification of pyrogenic activity. Variability on phytolith concentrations can results from the use of plants in combustion structures but also from the deposition of concentrated un-burnt plant materials, as evidenced by hypothesized collapsed thatch roof. It is therefore essential to identify whether the phytoliths have been exposed to fire or not (see Elbaum et al. 2003 for method to identify burnt phytolith). Charcoal and wood ash (if preserved) on the other hand are a direct evidence of burning but their presence alone cannot be used to link the deposit to intact combustion features, as they can both also be found in waste areas in secondary contexts. The use of micromorphology must be applied to complement the other proxies and provide crucial information about the deposition history and the context of the archaeological residues. We suggest that only the use of a multiproxy approach can produce a reliable identification of fire residues, in particular in environment with relatively poor preservation such as humid tropical forests. 


\section{Conclusions}

The use of fire among hunter-gatherers involve open and ephemeral fireplaces which are active for a short period of time and use mostly small branches, twigs and some logs. Hearths are not constructed and kept with low fire intensities. Such a fire leaves a low signal of partly charred wood, charcoal and ash. Daily rake-out and cleaning activities, especially sweeping of floors, clear the primary location of the hearth from most fire residues and re-deposits them in waste areas. The relatively rapid rate of accumulation in the waste areas allows better preservation of fire residues in this secondary context. Humid tropical environments are characterised by acidic conditions $(\mathrm{pH}<7)$ that result in the rapid and complete dissolution of ash and bones. Yet, charcoal, phytoliths and certain elements (mostly $\mathrm{P}$ and $\mathrm{Mg}$, and to some extent $\mathrm{Sr}$ ) tend to preserve better under such conditions and can be used as indicators for the use of fire. Sites located in carbonate-rich environment (e.g, on limestone or within a karstic system) are less likely to allow acidic conditions, thus preservation of carbonates (e.g., wood ash, bones and shells) will be significantly improved. Intensive biological activity within the sediments disturb the sedimentary sequence and challenge the preservation of fire residues as well as the identification of primary activity contexts. Alongside the identification of different microscopic fire residues (e.g., charcoal, ash, burnt bone and shells, burnt soil, phytoliths and indicative elements), the use of micromorphology is crucial for understanding deposition patterns. A multi-proxy geoarchaeological approach has the potential to successfully identify fire residues and their formation processes in tropical forests and even in open-air sites.

\section{Acknowledgment}

We are indebted to the Nayaka people who welcomed us and let us live with them and study their sites and ways of living. We would also like to thank Carolina Mallol and the participants at the Ethnoarchaeology of Fire Symposium in University of La Laguna for their helpful comments that helped to improve the manuscript. We thank Tonko Rajkovaca for his help in the production of thin sections. This work was supported by the People Programme (Marie Curie Actions) of the European Union's Seventh Framework Programme (FP7/2007-2013) under REA agreement $n^{\circ} 623293$ granted to D.E.F. at the McDonald Institute for Archaeological Research, University of Cambridge. 


\section{References}

Aceituno, F.J., Loaiza, N., Delgado-Burbano, M.E., Barrientos, G., 2013. The initial human settlement of Northwest South America during the Pleistocene/Holocene transition: Synthesis and perspectives. Quat. Int. 301, 23-33.

Anderson, D.D., 1997. Cave archaeology in Southeast Asia. Geoarchaeology. 12, 607-638.

Araujo, A.G., Feathers, J.K., Arroyo-Kalin, M., Tizuka, M.M., 2008. Lapa das boleiras rockshelter: stratigraphy and formation processes at a paleoamerican site in Central Brazil. J. Archaeol. Sci. 35, 3186-3202.

Barker, G., Barton, H., Bird, M., Daly, P., Datan, I., Dykes, A., Farr, L., Gilbertson, D., Harrisson, B., Hunt, C., Higham, T., 2007. The 'human revolution' in lowland tropical Southeast Asia: the antiquity and behavior of anatomically modern humans at Niah Cave (Sarawak, Borneo). J. Hum. Evol. 52, 243-261.

Barker, G. (Ed.), 2013. Rainforest Foraging and Farming in Island Southeast Asia, Vol. 1: The Archaeology of the Niah Caves, Sarawak. McDonald Institute for Archaeological Research, Cambridge.

Bar-Yosef, O., Eren, M.I., Yuan, J., Cohen, D.J., Li, Y., 2012. Were bamboo tools made in prehistoric Southeast Asia? An experimental view from South China. Quat. Int. 269, 9-21.

Berna, F., Goldberg, P., Horwitz, L.K., Brink, J., Holt, S., Bamford, M., Chazan, M., 2012. Microstratigraphic evidence of in situ fire in the Acheulean strata of Wonderwerk Cave, Northern Cape province, South Africa. PNAS. 109, 1215-1220.

Bellomo, R.V., 1994. Methods of determining early hominid behavioral activities associated with the controlled use of fire at FxJj 20 Main, Koobi Fora, Kenva. J. Hom. Evol. 27, 173-195.

Bentsen, S.E., 2014. Using pyrotechnology: Fire-related features and activities with a focus on the African Middle Stone Age. J. Archaeol. Res. 22, 141-175.

Binford, L.R., 1978. Dimensional Analysis of Behavior and Site Structure: Learning from an Eskimo Hunting Stand. Am. Antiq. 43, 330-361.

Bird-David, N., 1994. Sociality and immediacy: or, past and present conversations on bands. Man 29, 583-603.

Bird-David, N., 1999. "Animism" Revisited. Curr. Anthropol. 40, 67-91.

Bird-David, N., 2009. Indigenous architecture and relational senses of personhood: a cultural reading of changing dwelling styles among forest-dwelling foragers. Des. Princ. Pract. 3, 203-210.

Bird-David, N., 2017. Us, relatives: scaling and plural life in a forager world. University of California Press, Berkley.

Boriskovsky, P., 1967. Problems of the Palaeolithic and of the Mesolithic of the Southeast Asia, in: Solheim, W. (Ed.), Archaeology at the Eleventh Pacific Science Congress, Asian and Pacific Archaeology Series vol. 1. Social Science Research Institute, University of Hawaii, pp.41-46. 
Briggs, J.L., 1970. Never in anger: Portrait of an Eskimo family. Harvard University Press, Cambridge.

Bronk-Ramsey, C., 1995. Radiocarbon Calibration and Analysis of Stratigraphy: the OxCal Program. Radiocarbon 37, 425-430.

Bronk-Ramsey, C., 2001. Development of the Radiocarbon Program OxCal. Radiocarbon 43, $355-$ 363.

Bronk-Ramsey, C., 2010. https://c14.arch.ox.ac.uk/oxcal.html

Brown, K.S., Marean, C.W., Herries, A.I., Jacobs, Z., Tribolo, C., Braun, D., Roberts, D.L., Meyer, M.C., Bernatchez, J., 2009. Fire as an engineering tool of early modern humans. Science 325, 859862.

Brumm, A., 2010. The Movius line and the bamboo hypothesis: early hominin stone technology in Southeast Asia. Lithic Technology 35, 7-24.

Clark, J.D., Harris, J.W., 1985. Fire and its roles in early hominid lifeways. Afr. Archaeol. Rev. 3, 327.

David, N., Kramer, C., 2001. Ethnoarchaeology in action. Cambridge University Press, Cambridge.

Elbaum, R., Weiner, S., Albert, R.M., Elbaum, M., 2003. Detection of burning of plant materials in the archaeological record by changes in the refractive indices of siliceous phytoliths. J. Archaeol Sci. $30,217-226$.

Endicott, K.M., 1979. Batek Negrito religion: The world-view and rituals of a hunting and gathering people of Peninsular Malaysia. Oxford University Press, Oxford.

Fisher, J.W., Strickland, H.C., 1989. Ethnoarchaeology among the Efe Pygmies, Zaire: Spatial organization of campsites. Am. J. Physical Anthropol. 78, 473-484.

Forget, M.C., Regev, L., Friesem, D.E., Shahack-Gross, R., 2015. Physical and mineralogical properties of experimentally heated chaff-tempered mud bricks: Implications for reconstruction of environmental factors influencing the appearance of mud bricks in archaeological conflagration events. J. Archaeol. Sci. Rep. 2, 80-93.

Friesem, D.E. 2016. Geo-Ethnoarchaeology in action. J. Archaeol. Sci. 70, 145-157.

Friesem, D.E., Tsartsidou, G., Karkanas, T., Shahack-Gross, R., 2014a. Where are the roofs? A geoethnoarchaeological study of mud brick structures and their collapse processes, focusing on the identification of roofs. Archaeol. Anthropol Sci. 6. 73-92.

Friesem, D.E., Zaidner, Y., Shahack-Gross, R., 2014b. Formation processes and combustion features at the lower layers of the Middle Palaeolithic open-air site of Nesher Ramla, Israel. Quat. Int. 331, $128-138$.

Friesem, D.E., Lavi, N., 2017. Foragers, tropical forests and the formation of archaeological evidences: an ethnoarchaeological view from South India. Quat. Int.

doi:10.1016/j.quaint.2016.06.036. 
Friesem, D.E., Lavi, N., Madella, M., P. Ajithprasad, French, C., 2016. Site Formation Processes and Hunter-Gatherers Use of Space in a Tropical Environment: A Geo-Ethnoarchaeological Approach from South India. PLoS One 11, e0164185.

Gardner, P.M., 2000. Bicultural versatility as a frontier adaptation among Paliyan foragers of South India. Edwin Mellen Press, Lewiston.

Gargett, R., Hayden, B. 1991. Site structure, kinship, and sharing in aboriginal Australia, in: Kroll, E.M., Price, T.D. (Eds.), The Interpretation of Archaeological Spatial Patterning, Plenum Press, New York, pp. 11-32.

Gillieson, D.S., Mountain, M.J., 1983. Environmental History of Nombe Rockshelter, Papua New Guinea Highlands in Environment and People in Australia and the Pacific. Archaeology in Oceania, $18,53-62$.

Gnecco, C., Mora, S., 1997. Late Pleistocene/early Holocene tropical forest occupations at San Isidro and Pena Roja, Colombia. Antiq. 71, 683-690.

Goldberg, P., Macphail, R.I., 2008. Practical and theoretical geoarchaeology. Blackwell, Oxford.

Goldberg, P., Miller, C.E., Mentzer, S.M., 2017. Recognizing fire in the Paleolithic archaeological record. Curr. Anthropol. 58 (suppl. 16), SXXX-SXXX

Goren-Inbar, N., Alperson, N., Kislev, M.E., Simchoni, O., Melamed, Y., Ben-Nun, A., Werker, E., 2004. Evidence of hominin control of fire at Gesher Benot Yaaqov, Israel. Sci. 304, 725-727.

Gorman, C.F. 1969. Hoabinhian: a pebble-tool complex with early plant associations in southeast Asia. Sci. 163, 671-673.

Gorman, C.F. 1971. The Hoabinhian and after: subsistence patterns in Southeast Asia during the Late Pleistocene and early recent periods. World Archaeol. 2, 300-320.

Gosden, C. 2010. When humans arrived in the New Guinea highlands. Sci. 330: 41-42.

Hewlett, B.S., 1993. Intimate fathers: The nature and context of Aka Pygmy paternal infant care. University of Michigan Press, Ann Arbor.

Hewlett, B., Van De Koppel, J.M., Cavalli-Sforza, L.L., 1982. Exploration ranges of Aka pygmies of the Central African Republic. Man 17, 418-430.

Hutterer, K.L. 1976. An evolutionary approach to the Southeast Asian cultural sequence. Curr. Anthropol. 17, 221-242.

Jackson, M. 1995. At home in the world. Duke University Press, Durham and London.

Karkanas, P., Shahack-Gross, R., Ayalon, A., Bar-Matthews, M., Barkai, R., Frumkin, A., Gopher, A., Stiner, M.C., 2007. Evidence for habitual use of fire at the end of the Lower Paleolithic: Siteformation processes at Qesem Cave, Israel. J. Hum. Evol. 53, 197-212.

Kourampas, N., Simpson, I.A., Perera, H.N., Deraniyagala, S.U., 2008. Late Pleistocene huntergatherers in the South Asian rainforest: geoarchaeology of inhabited rockshelters in south-western Sri Lanka. Antiq. 82. http://www.antiquity.ac.uk/projgall/kourampas/ 
Kourampas, N., Simpson, I.A., Perera, N., Deraniyagala, S.U., Wijeyapala, W.H., 2009. Rockshelter sedimentation in a dynamic tropical landscape: Late Pleistocene-Early Holocene archaeological deposits in Kitulgala Beli-lena, southwestern Sri Lanka. Geoarchaeology 24, 677-714.

Lavi, N., Bird-David, N., 2014. At home under development: a housing project for the huntergatherers Nayaka of the Nilgiris. East. Anthropol. 67, 407-432.

Lewis, H. 2007. Preliminary soil micromorphology studies of landscape and occupation history at Tabon Cave, Palawan, Philippines. Geoarchaeology 22, 685-708.

Lewis, H., 2016. Soil Micromorphological Study of Cultural Sediments in the Niah Caves, in: Barker, G., Farr,L. (Eds.), Archaeological investigations in the Niah Caves, Sarawak. McDonald Institute for Archaeological Research, Cambridge, pp. 105-126.

Lycett, S. Bae, C., 2010. The Movius Line controversy: the state of the debate. World Archaeol. 42, 521-544.

Madella, M., Lancelotti, C., 2012. Taphonomy and phytoliths: a user manual. Quat. Int. 275, 76-83.

Magee, J., 1988. Oriented soil samples from the Tingkayu Basin, in: Bellwood, P. (Ed.),

Archaeological Research in South-eastern Sabah, Museum Monograph 2. Sabah Museum and State

Archives, Kota Kinabalu, pp. 31-37.

Mallol, C., Henry, A., 2017. Ethnoarchaeology of Paleolithic Fire: Methodological Considerations. Curr. Anthropol. 58(S16), SXXX-SXXX.

Mallol, C., Marlowe, F.W., Wood, B.M., Porter, C.C., 2007. Earth, wind, and fire: ethnoarchaeological signals of Hadza fires. J. Archaeol. Sci. 34, 2035-2052.

Mallol, C., Mentzer, S.M., Miller, C.E., 2017. Combustion features, in: Nicosia, C., Stoops, G. (Eds.), Archaeological soil and sediment micromorphology. Wiley, Chichester.

Mentzer, S.M. 2014. Microarchaeological approaches to the identification and interpretation of combustion features in prehistoric archaeological sites. J. Archaeol. Method Theory 21, 616-668.

Mercader, J. 2002. Forest people: the role of African rainforests in human evolution and dispersal. Evol. Anthropol. 11, 117-124.

Mercader, J. (Ed.), 2003a. Under the Canopy: The Archaeology of Tropical Rain Forests. Rutgers University Press, Piscataway.

Mercader, J., Marti, R., 2003. The Middle Stone Age Occupation of Atlantic Central Africa: New Evidence from Equatorial Guinea and Cameroon, in: Mercader, J. (ed.), Under the Canopy: The Archaeology of Tropical Rain Forests. Rutgers University Press, Piscataway, pp. 64-92.

Mercader, J., Martí, R., Martinez, J.L., Brooks, A., 2002. The nature of 'stone-lines' in the African Quaternary record: archaeological resolution at the rainforest site of Mosumu, Equatorial Guinea. Quat. Int. 89, 71-96.

Mercader, J., Mart1, R., González, I.J., Sánchez, A., Garcia, P., 2003b. Archaeological site formation in rain forests: insights from the Ituri rock shelters, Congo. J. Archaeol. Sci. 30, 45-65. 
Middleton, W.D. Price, D.T., 1996. Identification of activity areas by multi-element characterization of sediments from modern and archaeological house floors using inductively coupled plasma-atomic emission spectroscopy. J. Archaeol. Sci. 23, 673-687.

Mijares, A.S.B., Lewis. H.A., 2009. Cave sites in northeastern Luzon, Philippines: A preliminary soil micromorphological study. Asian Perspectives 48, 98-118.

Milek, K.B. 2012. Floor formation processes and the interpretation of site activity areas: an ethnoarchaeological study of turf buildings at Thverá, northeast Iceland. J. Anthropol. Archaeol. 31, 119-137.

Morley, M.W., 2017. The geoarchaeology of hominin dispersals to and from tropical Southeast Asia: A review and prognosis. J. Archaeol. Sci. 77, 78-93.

Morley, M.W., Goldberg, P., 2017. Geoarchaeological research in the humid tropics: A global perspective. J. Archaeol. Sci. 77, 1-9.

Morley, M.W., Goldberg, P., Sutikna, T., Tocheri, M.W., Prinsloo, L.C., Saptomo, E.W., Wasisto, S., Roberts, R.G., 2017. Initial micromorphological results from Liang Bua, Flores (Indonesia): Site formation processes and hominin activities at the type locality of Homo floresiensis. J. Archaeol. Sci. $77,125-142$.

Morris, B., 1982. Forest traders: a socio-economic study of the Hill Pandaram. Athlone Press, London.

Myers, F. 1986. Pintupi country, Pintupi self: Sentiment, place, and politics among Western Desert Aborigine. Smithonian Institution Press and Australian Institute of Aboriginal Studies, Washington.

O'Connell, J.F. 1987. Alyawara site structure and its archaeological implications. Am. Antiq. 52, 74108.

O'Connell, J.F., Hawkes, K., Jones, N.B., 1991. Distribution of refuse-producing activities at Hadza residential base camps, in: Kroll, E.M., Price, D.T. (Eds.), The Interpretation of Archaeological Spatial Patterning, Plenum Press, New-York, pp. 61-76.

Perera, N. 2010. Prehistoric Sri Lanka: Late Pleistocene Rockshelters and an Open Air Site. BAR International Series. Archaeopress, Oxford.

Pope, G.G. 1989. Bamboo and human evolution. Nat. History 10, 49-57.

Rabett, R., Appleby, J., Blyth, A., Farr, L., Gallou, A., Griffiths, T., Hawkes, J., Marcus, D., Marlow, L., Morley, M., Tân, N.C., 2011. Inland shell midden site-formation: Investigation into a late Pleistocene to early Holocene midden from Trang An, Northern Vietnam. Quat. Int. 239, 153-169.

Rabett, R., Ludgate, N., Stimpson, C., Hill, E., Hunt, C., Ceron, J., Farr, L., Morley, M., Reynolds, T., Zukswert, H., Simpson, D., 2017. Tropical limestone forest resilience and late Pleistocene foraging during MIS-2 in the Tràng An massif, Vietnam. Quat. Intl. doi:10.1016/j.quaint.2016.06.010.

Reimer, P.J., Bard, E., Bayliss, A., Beck, J.W., Blackwell, P.G., Ramsey, C.B., Buck, C.E., Cheng, H., Edwards, R.L., Friedrich, M., Grootes, P.M., 2013. IntCal13 and Marine13 radiocarbon age calibration curves 0-50,000 years cal BP. Radiocarbon 55, 1869-1887. 
Reynolds, T.E.G., 2007. Problems in the stone age of South-east Asia revisited. Proc. Prehist. Soc. $73,39-58$.

Roberts, P., Petraglia, M., 2015. Pleistocene rainforests: barriers or attractive environments for early human foragers?. World Archaeol. 47, 718-739.

Roberts, P., Perera, N., Wedage, O., Deraniyagala, S., Perera, J., Eregama, S., Gledhill, A., Petraglia, M.D., Lee-Thorp, J.A., 2015. Direct evidence for human reliance on rainforest resources in late Pleistocene Sri Lanka. Science 347, 1246-1249.

Roebroeks, W., Villa, P., 2011. On the earliest evidence for habitual use of fire in Europe. PNAS 108, 5209-5214.

Rondelli, B., Lancelotti, C., Madella, M., Pecci, A., Balbo, A., Pérez, J.R., Inserra, F., Gadekar, C., Ontiveros, M.Á.C., Ajithprasad, P., 2014. Anthropic activity markers and spatial variability: an ethnoarchaeological experiment in a domestic unit of Northern Gujarat (India). J. Archaeol. Sci. 41, 482-492.

Roosevelt, A.C., Da Costa, M.L., Machado, C.L., Michab, M., 1996. Paleoindian cave dwellers in the Amazon: the peopling of the Americas. Science 272, 373.

Shahack-Gross, R., 2017. Archaeological formation theory and geoarchaeology: State-of-the-art in 2016. J. Archaeol. Sci. 79, 36-43.

Shimelmitz, R., Kuhn, S.L., Jelinek, A.J., Ronen, A., Clark, A.E., Weinstein-Evron, M., 2014. 'Fire at will': The emergence of habitual fire use 350,000 years ago. J. Hum. Evol. 77, 196-203.

Simpson, I., Kourampas, N., Perera, H.N., 2008. Bellan-bandi Palassa, Sri Lanka: Formation processes of a Mesolithic open-air site identified through thin section micromorphology. Archaeologia 4, 3-18.

Solheim, W.G., 1972. The "new look" of Southeast Asian prehistory. J. Siam Soc. 60, 1-20.

Stephens, M., Rose, J., Gilbertson, D.D., Canti, M.G., 2005. Micromorphology of cave sediments in the humid tropics: Niah Cave, Sarawak. Asian Perspectives 44, 42-55.

Stephens, M., Rose, J., Gilbertson, D.D., 2017. Post-depositional alteration of humid tropical cave sediments: micromorphological research in the great cave of Niah, Sarawak, Borneo. J. Archaeol. Sci. $77,109-124$.

Stuiver, M., Polach, H.A., 1977. Discussing reporting C-14 data. Radiocarbon 19, 355-363.

Summerhayes, G.R., Leavesley, M., Fairbairn, A., Mandui, H., Field, J., Ford, A., Fullagar, R., 2010. Human adaptation and plant use in highland New Guinea 49,000 to 44,000 years ago. Science 330, 78-81.

Summerhayes, G.R., Field, J.H., Shaw, B., Gaffney, D., 2017. The archaeology of forest exploitation and change in the tropics during the Pleistocene: the case of Northern Sahul (Pleistocene New Guinea). Quat. Int. doi:10.1016/j.quaint.2016.04.023

Turnbull, C.M., 1965. Wayward servants: The two worlds of the African Pygmies. Natural History Press, Garden City. 
Villagran, X.S., Strauss, A., Miller, C., Ligouis, B., Oliveira, R., 2017. Buried in ashes: site formation processes at Lapa do Santo rockshelter, east-central Brazil. J. Archaeol. Sci. 77, 10-34.

Weiner, S. 2010. Microarchaeology: beyond the visible archaeological record. Cambridge University press, Cambridge.

White, P.J. 1977. Crude, colourless and Unenterprising? Prehistorians and their views on the stone age of Sunda and Sahul, in: Allen, J., Golson, J., Jones, R. (Eds.), Sunda and Sahul. Prehistoric Studies in Southeast Asia, Melanesia and Australia. Academic Press, London, pp. 13-30.

Wilson, C.A., Davidson, D.A., Cresser, M.S., 2008. Multi-element soil analysis: an assessment of its potential as an aid to archaeological interpretation. J. Archaeol. Sci. 35, 412-424.

Woodburn, J. 1968. Stability and flexibility in Hadza residential groupings, in: Lee, R.B., DeVore, I. (Eds.), Man the Hunter, Aldine, Chicago, pp. 103-110.

Woodburn, J. 1972. Ecology, nomadic movement and the composition of the local group among hunters and gatherers; An East African example and its applications, in: Ucke, P.J. (Ed.), Man, settlement and urbanism, Duckworth, London, pp. 193-206.

Woodburn, J. 1982. Egalitarian societies. Man 17, 431-451.

Xhauflair, H., Pawlik, A., Dizon, E., 2012. How can stone tools help to understand the importance of plants in the subsistance strategies of prehistoric hunter-gatherers in the Philippines and Southeast Asia?, in: Tjoa-Bonatz, M.L., Reinecke, A., Bonatz, D. (Eds.), Crossing Borders, vol. 1, NUS Press, Singapore, pp. 26-34.

Xhauflair, H., Pawlik, A., Gaillard, C., Forestier, H., Vitales, T.J., Callado, J.R., Tandang, D., Amano, N., Manipon, D., Dizon, E., 2016. Characterisation of the use-wear resulting from bamboo working and its importance to address the hypothesis of the existence of a bamboo industry in prehistoric Southeast Asia. Quat. Int. 416, 95-125. 


\section{$\underline{\text { Figure Captions }}$}

Fig. 1. Map of India showing the location of fieldwork (white circle) in the hills of the Western Ghats in South India. The Blue Marble Next Generation data is courtesy of Reto Stockli (NASA/GSFC) and NASA's Earth Observatory. NASA/Goddard Space Flight Center Scientific Visualization Studio. The country data is taken from the: CIA World DataBank II.

Fig. 2. The life cycle of a hearth among the Nayaka : a) active hearth being used made of thin branches and kept a low fire; (b) the hearth is left to die, note the presence of ashes, charcoal and unburnt wood; (c) hearth are being cleared and swept, note the absence of charcoal in the original place of the hearth which are redeposit over the terrace edge in the waste area; (d) a new fire is being placed just after sweeping near the swept hearth but not in the exact same location. Note the pile of firewood by its side and the traces of the swept hearth still noticeable.

Fig. 3. The dynamic and ephemeral nature of hearths. (a) Day 1, a hearth was left to die near the pole in the center of the terrace. Note that this hearth also uses a partly burnt thick log; (b) Day 2, the terrace after the rain, note the complete absence of any visible fire residues; (c) Morning of Day 4, the remains of a hearth used the previous night in a new location than the hearth of Day 1. Note the re-use of the thick log; (d) Noon of Day 4, the hearth is now abandoned as a new hearth has been placed elsewhere in the terrace; (e) Day 8, showing scarce remains, mostly ash and no charcoal, on the terrace floor.

Fig. 4. Field photographs of the samples. The large letters in the photographs indicate the location of the close-up photographs. The small letters refer to the sediment layers $[t=t o p ; m$ $=$ middle; $\mathrm{b}=$ bottom]. The red arrows mark the location of charcoal. In all photographs the scale bar is $20 \mathrm{~cm}$. (a) The sampling area of the terrace in the contemporary site; (b) The recently abandoned hearth. Note the grey appearance of the thin ashy layer on the surface; (c) The terrace sediment no longer showing traces for hearths which were previously placed there; (d) The open-air site during excavation showing the trench across the exterior activity terrace. Note the debris of the decayed mud house in the background and the slope over the edge of the terrace in the right part of the photograph; (e) The profile of the trench in the terrace; (f) The profile of the trench in the slope; (g) The trench in the rock-shelter where the 
charcoal horizon was found; (h) General photograph of the rock-shelter before excavation; (i) close-up on the charcoal horizon.

Fig. 5. Infrared spectra obtained through FTIR analysis. (a) The general sediment of the contemporary activity terrace surface showing clay [kaolinite] as the main mineral component. Note the absorbance bands indicative to unaltered kaolinite [1031, 914, 471, 533, $3443,3523,3620$ and $\left.3695 \mathrm{~cm}^{-1}\right]$; (b) The thin ashy layer from the contemporary site showing high amounts of calcite due to wood ash $\left[1432,874\right.$ and $\left.713 \mathrm{~cm}^{-1}\right]$, pyrogenic alteration of clay [note the shift of the main peak to $1042 \mathrm{~cm}^{-1}$ and the absence of peaks at 914, 530, 3525, 3620 and $3695 \mathrm{~cm}^{-1}$ ] and bone fragment [603 and $\left.573 \mathrm{~cm}^{-1}\right]$; (c) Sediment from the activity terrace in the abandoned open-air site showing unaltered kaolinite; (d) Sediment from the charcoal horizon found in the abandoned rock-shelter showing slightly altered kaolinite [ note the minor shift of the main peak to $1035 \mathrm{~cm}^{-1}$, the absence of a peak at $914 \mathrm{~cm}^{-1}$ and the very low peaks at 3525,3620 and $3695 \mathrm{~cm}^{-1}$ ]

Fig 6. Phytolith concentrations in the sediment samples. top=top sediment layer in the profile sampled; mid=middle sediment layer in the profile sampled; bot=bottom sediment layer in the profile sampled. The $\mathrm{x}$ marker represent control samples of regional sediment outside the site [ctrl]. The triangles represent samples from the contemporary site [cont. site] (Fig. 4a). samples were taken from the recently abandoned hearth (Fig. 4b) [tas=top ash layer; bas=below ash layer] and from a small trench in the terrace (Fig. 4c). The squares represent samples from the open-air site. Samples were collected from the trench in the exterior activity terrace (Fig. 4e) and the slope interpreted as the waste areas (Fig. 4f). Note that one sample in the middle of the profile in the terrace profile shows relatively high phytolith concentrations. The circles represent the samples from the trench in the rock-shelter where a charcoal horizon was revealed (Fig. 4g) [mch=middle sediment layer associated with the charcoal horizon]. Note the elevated concentration of phytolith within and above the charcoal horizon which is higher than the concentration in the ash layer in the contemporary site.

Fig. 7. Concentrations of phosphorous [P], calcium [Ca], magnesium [Mg], potassium [K] and strontium $[\mathrm{Sr}]$ within the sediment samples. [top=top sediment layer in the profile sampled; mid=middle sediment layer in the profile sampled; bot=bottom sediment layer in the profile sampled; tas=top ash layer collected from the recently abandoned hearth in the contemporary site; $m c h=$ middle sediment layer associated with the charcoal horizon in the 
rock-shelter]. The $\mathrm{x}$ marker represent control samples of regional sediment outside the site [ctrl]. The triangles represent samples from the contemporary site [cont. site]. The squares represent samples from the open-air site. The circles represent the samples from the trench in the rock-shelter.

Fig. 8. Microphotographs. (a) The profile of the terrace in the open-air site. Note the crumbly and disturbed structure of the sediment due to intensive activity of roots and animals within the sediment disrupting the sedimentary sequence; (b) The profile of the slope in the open-air site. Fragments of charcoal were found (red arrows) in secondary deposition indicative for discarded fire residues in waste areas; (c) close-up on a fragment of charcoal from the slope of the open-air site. Note that the charcoal is covered by clay which protect it from mechanical deterioration but still show disintegration due to the chemical conditions; (d) The profile in the rock-shelter presenting at the bottom a well-preserved charcoal horizon (red arrow), overlain by post-abandonment accumulation of sediment and a rich organic matter (o.m.) layer interpreted as the remains of a lean-to collapsed thatch roof. Note the presence of charcoal (red arrow) in the upper layer indicating the return of people to the site after the abandonment of the site and the collapse of the roof.

Table 1. Results of radiocarbon dating of charcoal samples. C-14 ages are reported in conventional radiocarbon years (before present $=1950$ ) in accordance with international convention (Stuiver and Polach 1977). All calculated C-14 ages have been corrected for the fractionation so as to refer the results to be equivalent with the standard $\delta 13 \mathrm{C}$ value of $-25 \%$ o (wood). Calibrated ages in calendar years have been obtained from the calibration tables (Reimer et al. 2013) by means of OxCal v. 4.2 of Bronk Ramsey (2010) (Bronk-Ramsey 1995; Bronk-Ramsey 2001). $\pm 1 \sigma$, meaning $68.2 \%$ probability that the true age is included in those limits; $\pm 2 \sigma$, meaning $95.4 \%$ probability that the true age is included in those limits.

Table 2. Summary of the formation processes (anthropogenic and environmental) associated with hunter-gatherer use of fire in tropical environment.

Table 3. Summary of the various proxies for the investigation of fire residues and their confidence. 


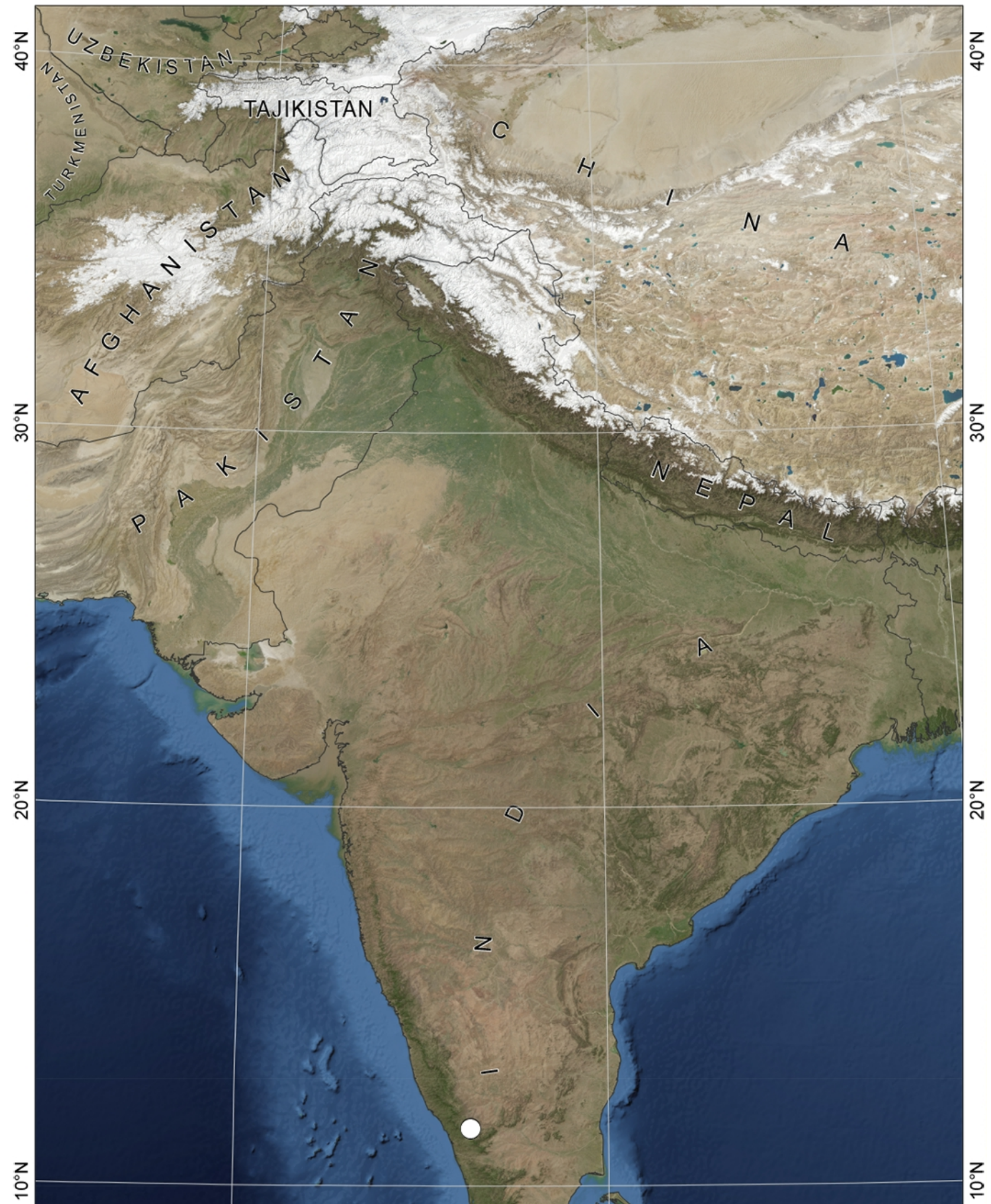




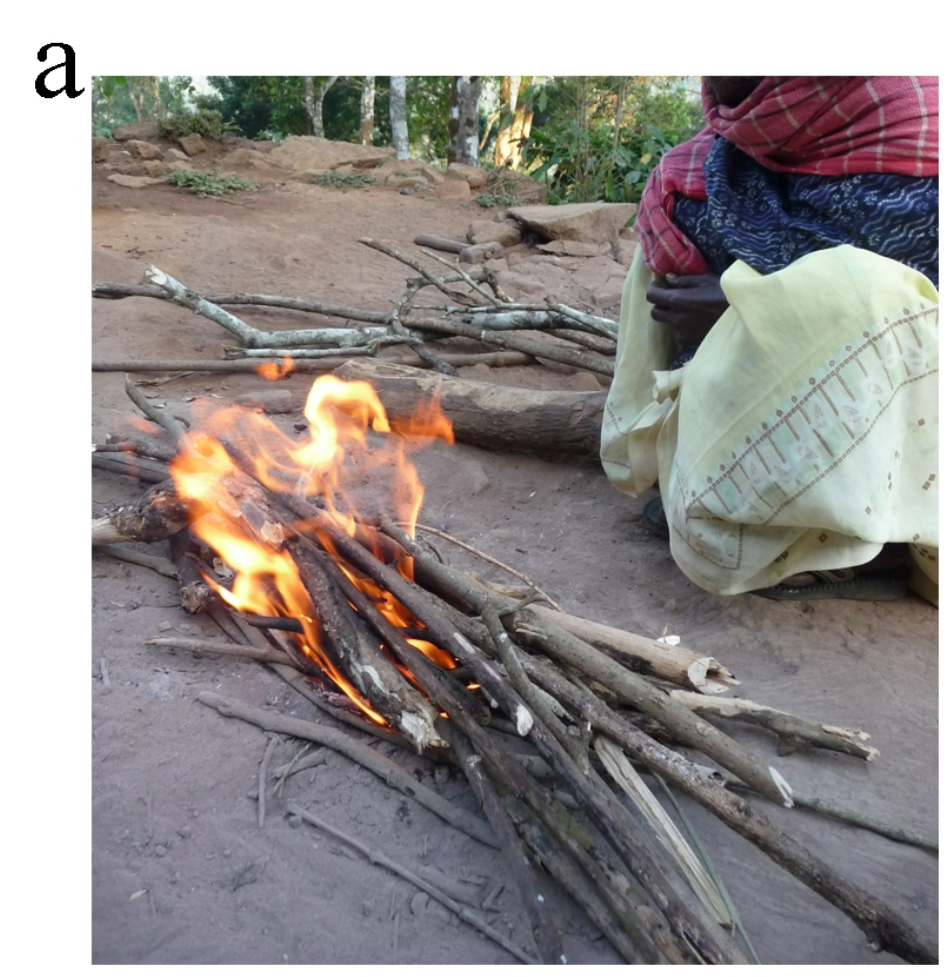

b

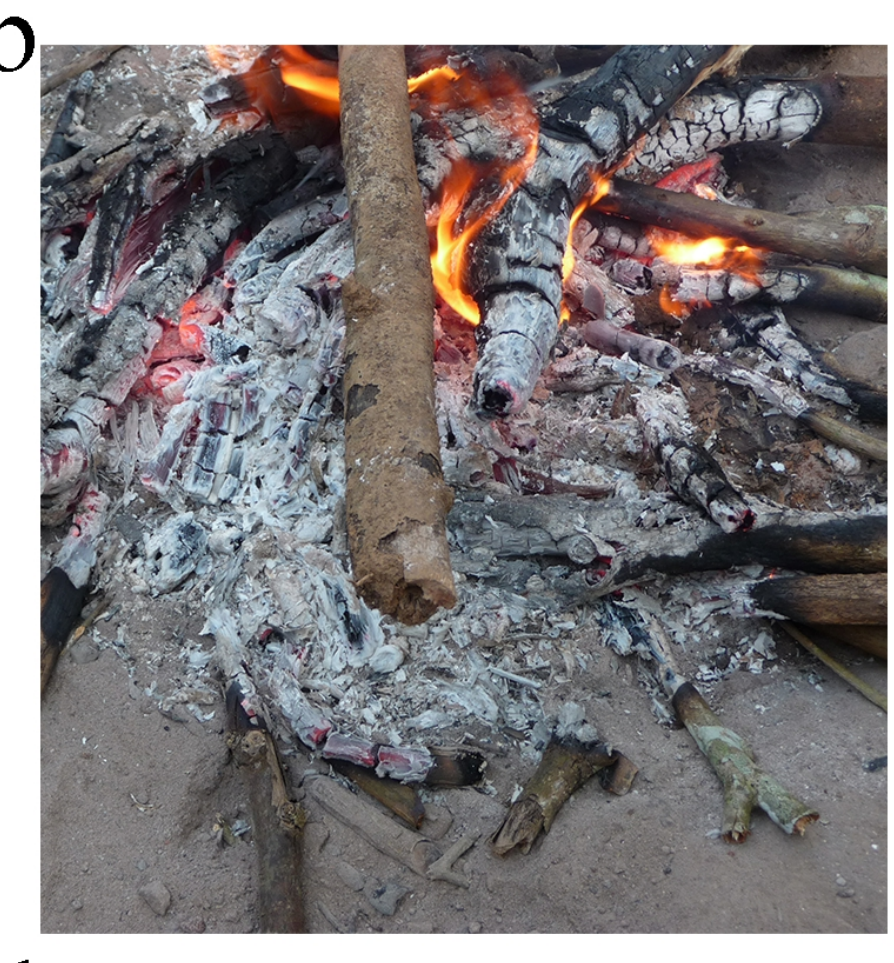

c

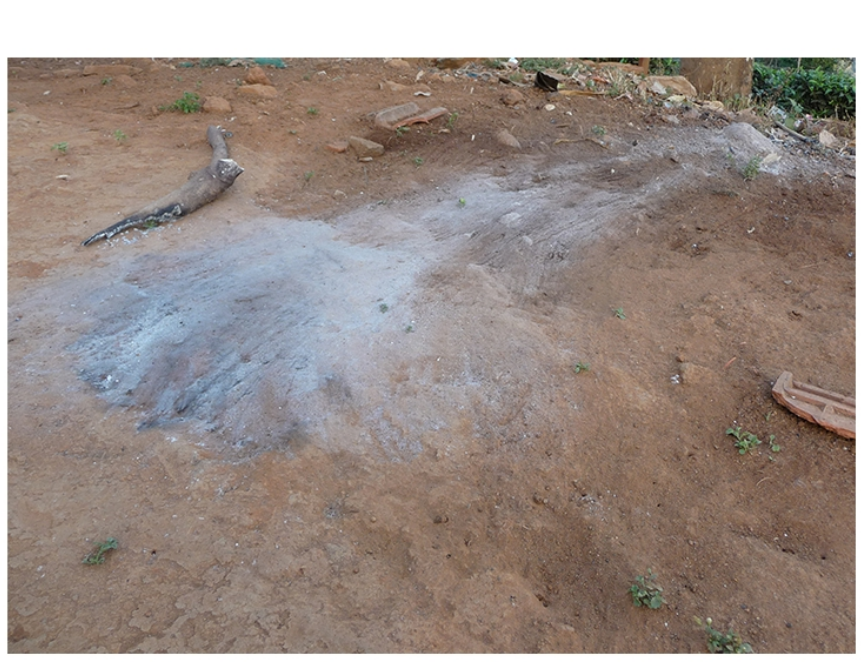

d

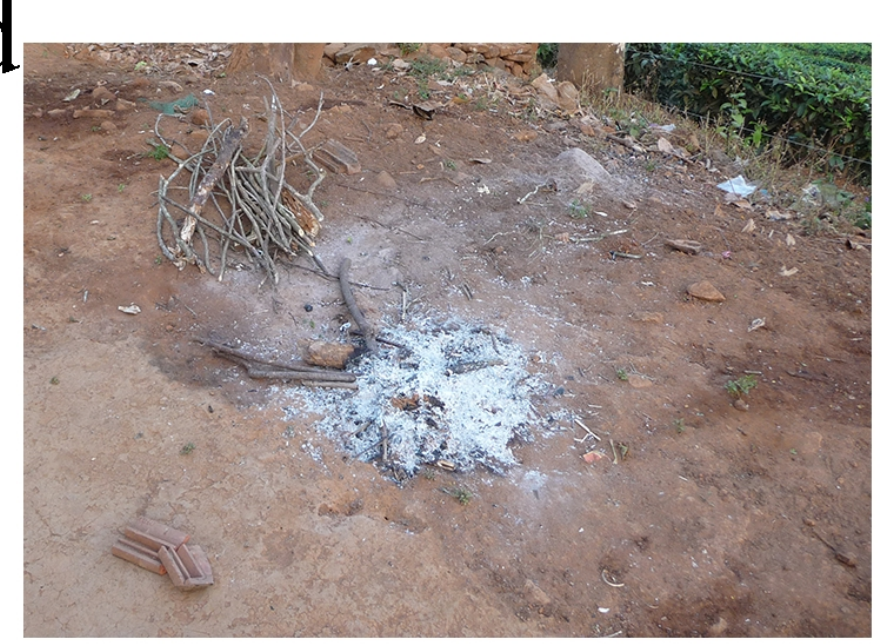


Day 1

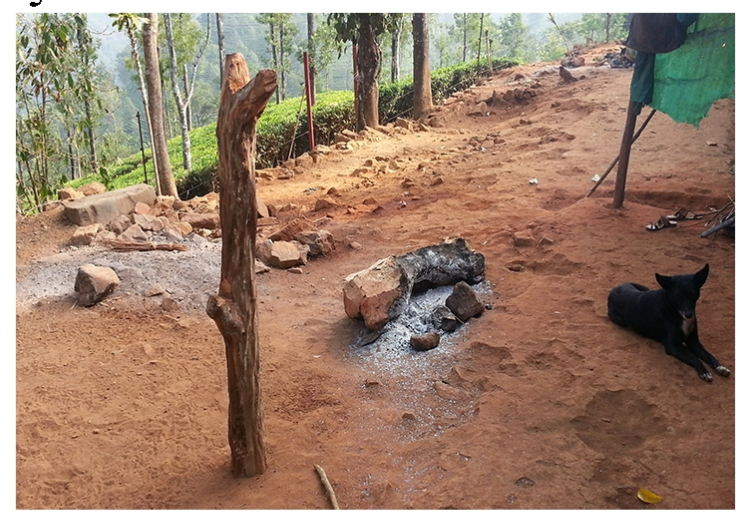

Day 4 morning

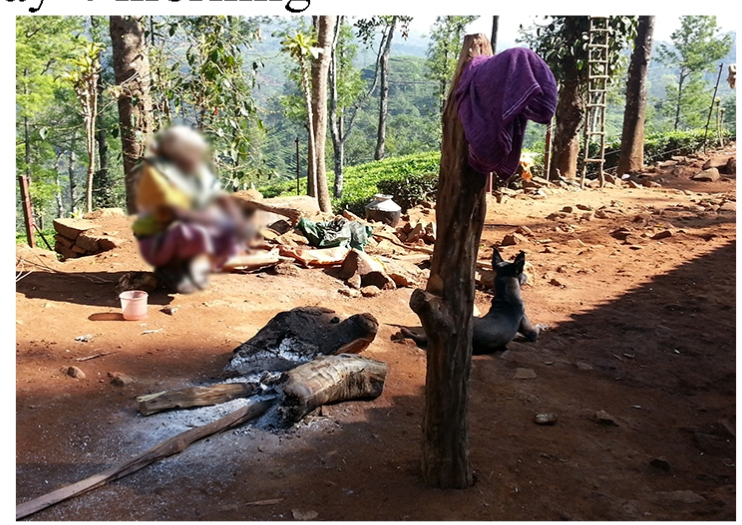

Day 2

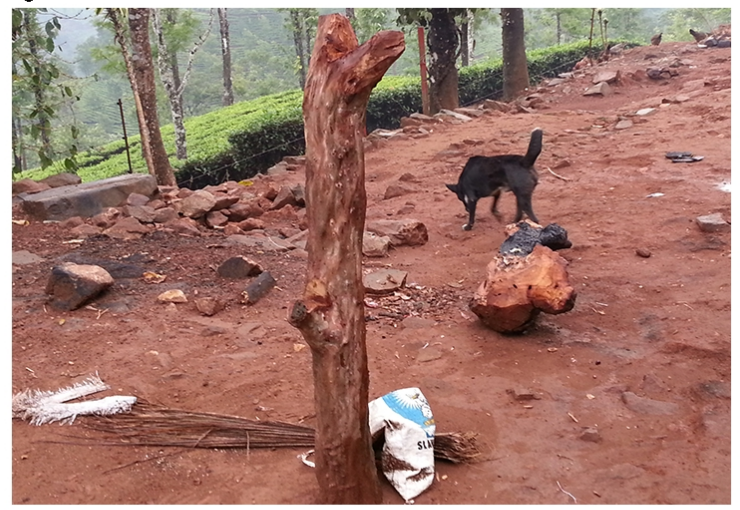

Day 4 noon

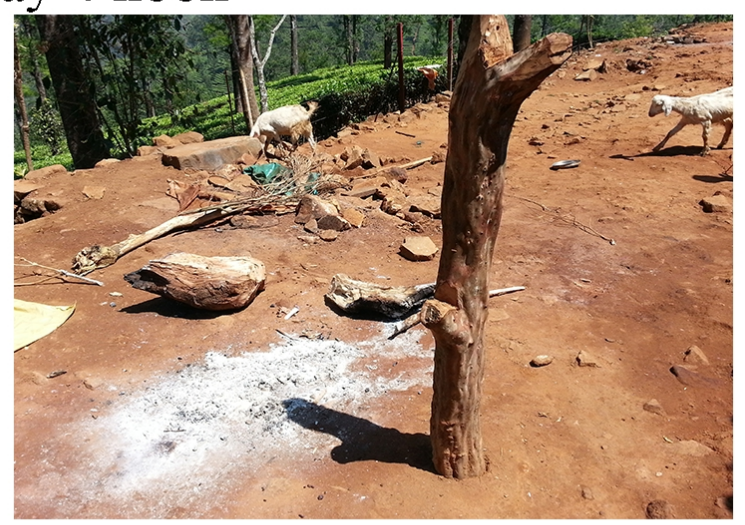

Day 8

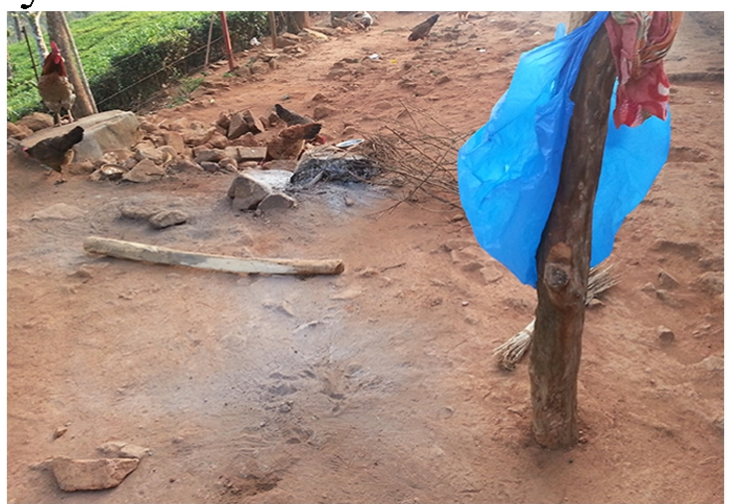



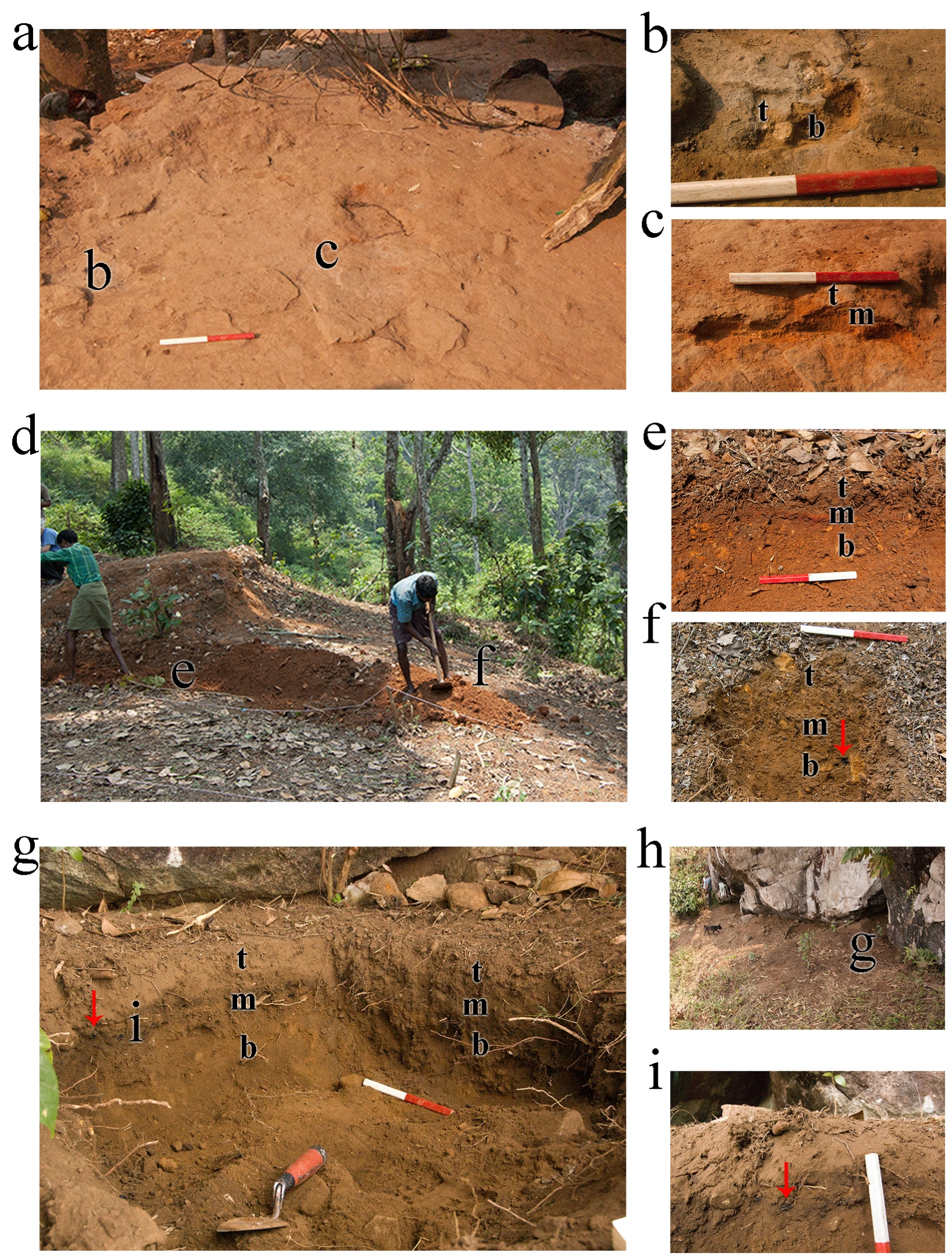


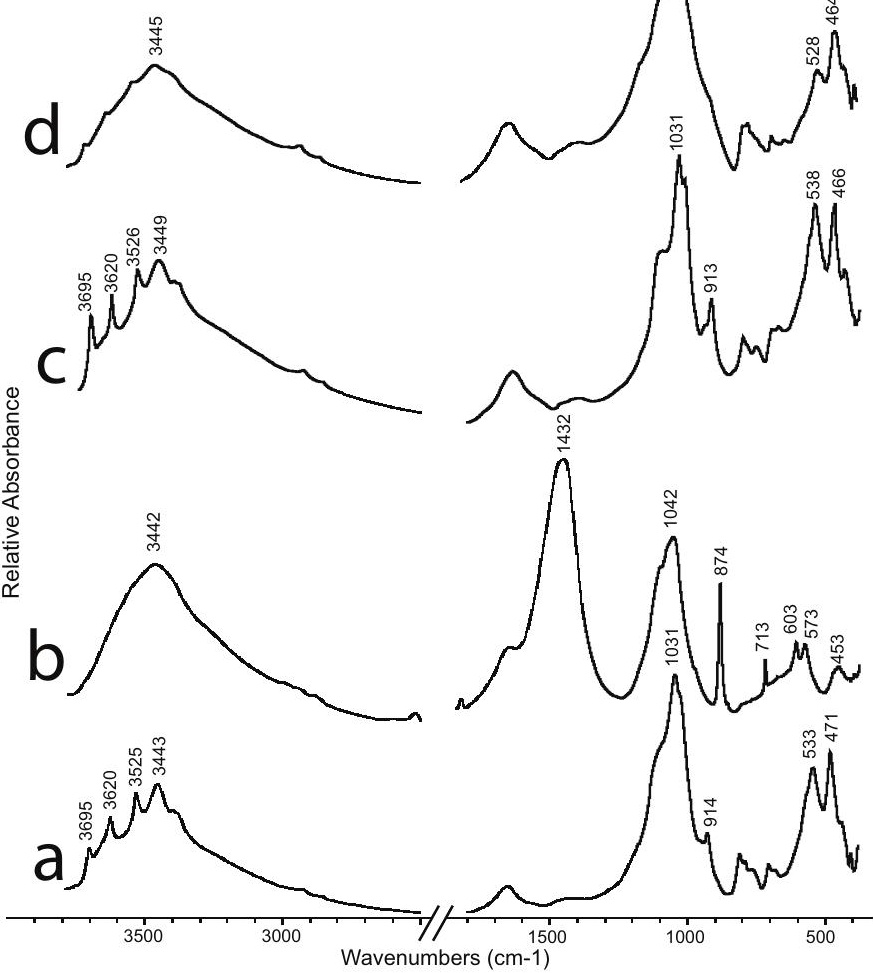




\section{Phytolith concentrations}

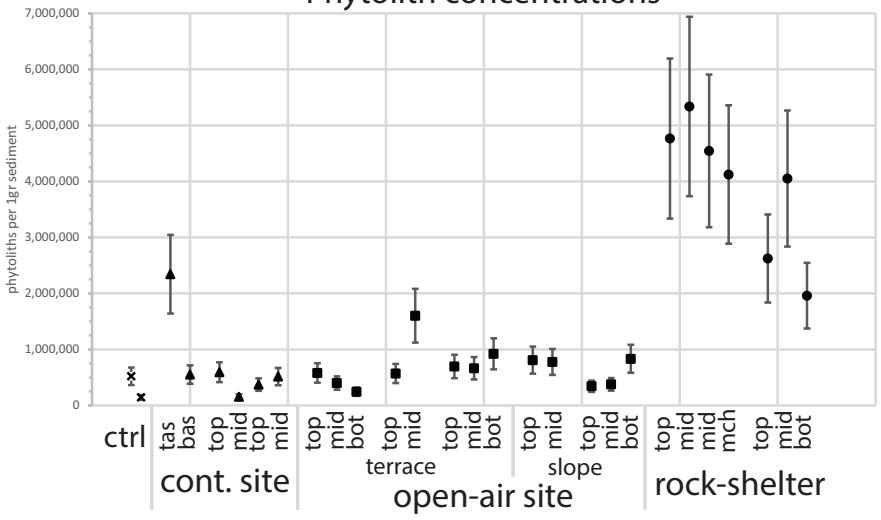


a

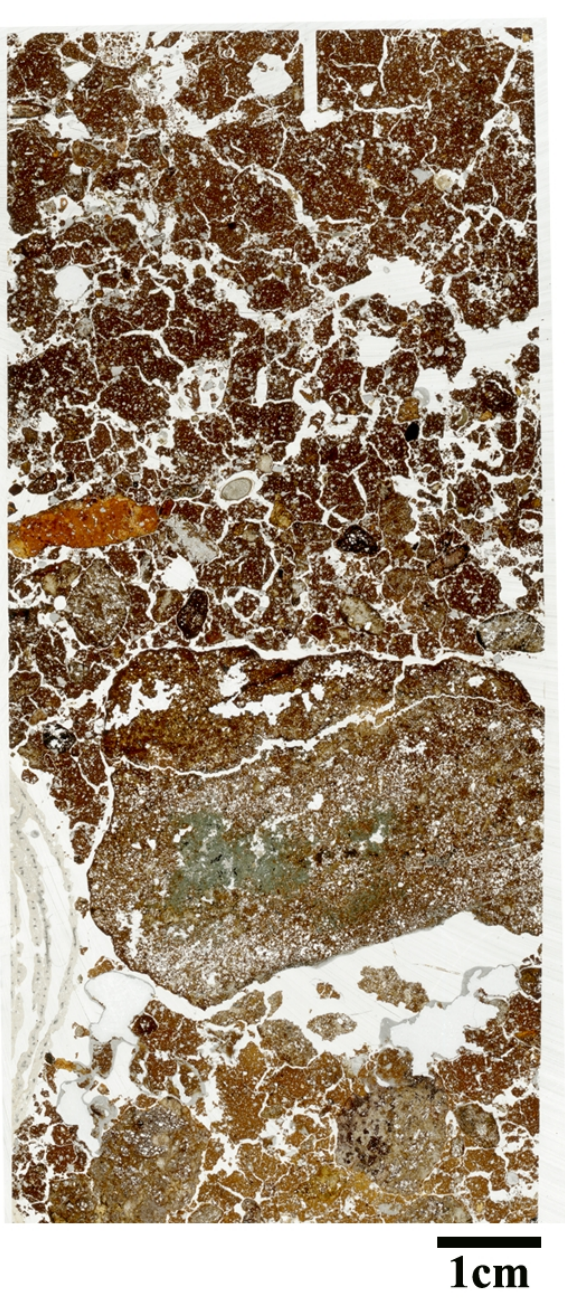

b
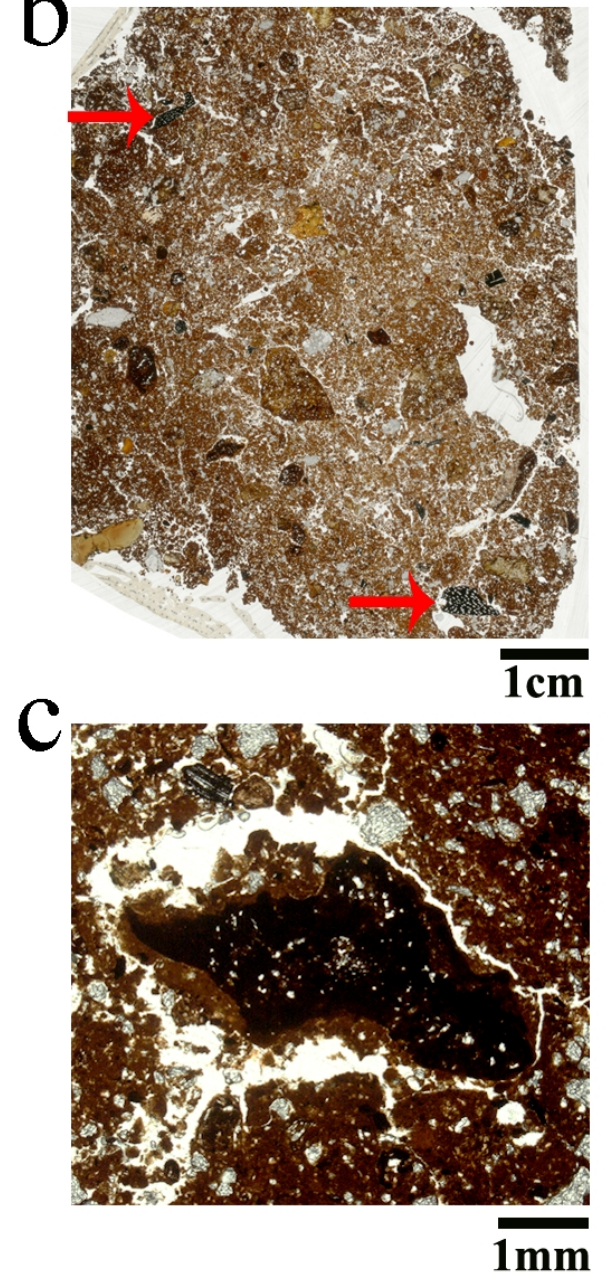

d

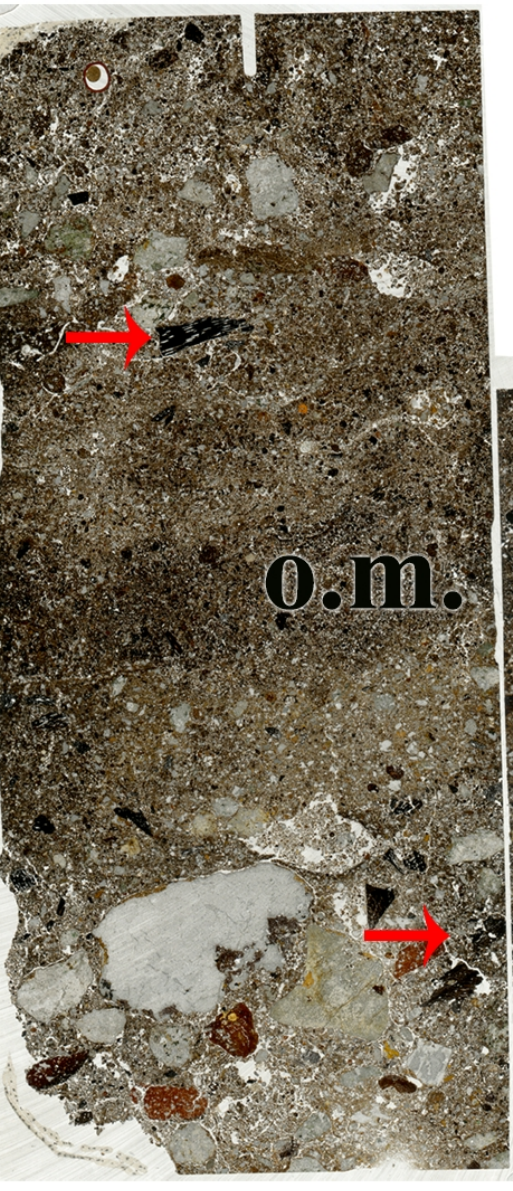

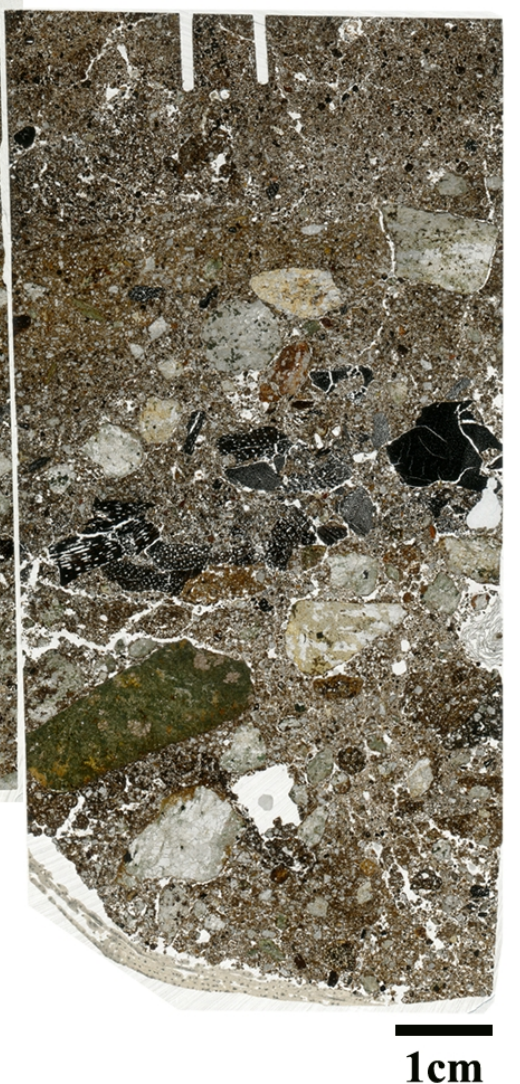


Table 1. Results of radiocarbon dating of charcoal samples. C-14 ages are reported in conventional radiocarbon years (before present =1950) in accordance with international convention (Stuiver and Polach 1977). All calculated C-14 ages have been corrected for the fractionation so as to refer the results to be equivalent with the standard $\delta^{13} \mathrm{C}$ value of $-25 \%$ (wood). Calibrated ages in calendar years have been obtained from the calibration tables (Reimer et al. 2013) by means of OxCal v. 4.2 of Bronk Ramsey (2010) (Bronk-Ramsey 1995; Bronk-Ramsey 2001).

\begin{tabular}{|c|c|c|c|c|c|c|c|c|}
\hline Sample & Site & Context & $\begin{array}{l}\text { Eff } \\
\%\end{array}$ & $\begin{array}{l}\mathrm{C} \\
\%\end{array}$ & $\mathrm{pMC} \pm 1 \sigma$ & $\begin{array}{l}\mathrm{C}-14 \text { age } \\
\pm 1 \sigma \\
\text { year } \mathrm{BP}\end{array}$ & $\begin{array}{l}\text { Calibrated range } \\
\pm 1 \sigma A D\end{array}$ & $\begin{array}{l}\text { Calibrated range } \\
\pm 2 \sigma A D\end{array}$ \\
\hline TM-37 & Open-air & Middle part of slope & 83.1 & 75.0 & $99.69 \pm 0.31$ & $25 \pm 25$ & $\begin{array}{l}1713(1.9 \%) 1715 \\
1891(59.9 \%) 1908 \\
1954(6.4 \%) 1955\end{array}$ & $\begin{array}{l}1698(11.4 \%) 1722 \\
1816(7.6 \%) 1834 \\
1878(69.8 \%) 1916 \\
1954(6.6 \%) 1955\end{array}$ \\
\hline TM-41 & Open-air & Lower part of slope & 74.9 & 70.0 & $103.05 \pm 0.32$ & & $1955(68.2 \%) 1956$ & $1955(95.4 \%) 1956$ \\
\hline TM-88 & Rock-shelter & Middle of site, upper part of profile & 73.4 & 69.4 & $134.12 \pm 0.37$ & & $1976(68.2 \%) 1977$ & $\begin{array}{l}1962 \text { ( 8.9\%) } 1962 \\
1976(70.6 \%) 1977 \\
1978(15.9 \%) 1978 \\
\end{array}$ \\
\hline TM-95 & Rock-shelter & Western part of site - Charcoal horizon & 72.7 & 54.7 & $98.39 \pm 0.31$ & $130 \pm 25$ & $\begin{array}{l}1682(10.0 \%) 1700 \\
1702(1.6 \%) 1706 \\
1719(8.9 \%) 1737 \\
1757(1.7 \%) 1761 \\
1804(7.7 \%) 1819 \\
1824(0.1 \%) 1824 \\
1833(26.3 \%) 1881 \\
1915(11.5 \%) 1936 \\
1954(0.3 \%) 1954\end{array}$ & $\begin{array}{l}1677(34.8 \%) 1766 \\
1772(1.2 \%) 1777 \\
1799(43.4 \%) 1893 \\
1906(15.0 \%) 1941 \\
1951(1.1 \%) 1954\end{array}$ \\
\hline TM-100 & Rock-shelter & Western part of site - Charcoal horizon & 56.5 & 61.3 & $98.41 \pm 0.31$ & $128 \pm 25$ & $\begin{array}{l}1682(10.0 \%) 1701 \\
1701(2.3 \%) 1707 \\
1719(8.6 \%) 1736 \\
1759(0.4 \%) 1760 \\
1805(7.5 \%) 1819 \\
1823(1.1 \%) 1825\end{array}$ & $\begin{array}{l}1678 \text { (34.1\%) } 1765 \\
1772 \text { (1.0\%) } 1777 \\
1800(44.4 \%) 1893 \\
1906(14.9 \%) 1940 \\
1951 \text { (1.0\%) } 1954\end{array}$ \\
\hline
\end{tabular}




\begin{tabular}{|l|l|l|l|l|l|l|l|l|}
\hline & & & & & & & $\begin{array}{l}1832(27.1 \%) 1881 \\
1914(10.9 \%) \\
1935 \\
1954(0.3 \%) 1954\end{array}$ \\
\hline TM-110 & Contemporary & Terrace surface & & & & & $2000(68.2 \%) 2002$ & $1957(6.3 \%) 1958$ \\
$2000(89.1 \%) 2002$
\end{tabular}


Table 2. Summary of the formation processes (anthropogenic and environmental) associated with hunter-gatherer use of fire in tropical environment.

\begin{tabular}{|l|l|l|l|l|l|}
\hline $\begin{array}{l}\text { Hunter-gatherer } \\
\text { use of fire }\end{array}$ & $\begin{array}{l}\text { Hearths are dynamic and } \\
\text { ephemeral }\end{array}$ & $\begin{array}{l}\text { Hearths are placed } \\
\text { outdoor }\end{array}$ & $\begin{array}{l}\text { Low fire and use of } \\
\text { branches and few logs }\end{array}$ & $\begin{array}{l}\text { Clearing of hearth and } \\
\text { sweeping }\end{array}$ & \\
\hline $\begin{array}{l}\text { Deposition } \\
\text { patterns }\end{array}$ & $\begin{array}{l}\text { No fixed or repetitive } \\
\text { activity areas }\end{array}$ & $\begin{array}{l}\text { Scattered outdoors all } \\
\text { over the habitation site }\end{array}$ & $\begin{array}{l}\text { Low intensity of fire } \\
\text { residues }\end{array}$ & $\begin{array}{l}\text { Secondary deposition } \\
\text { in waste areas }\end{array}$ & \\
\hline & & \multicolumn{1}{|c|}{ Acidity (pH<7) } & \\
\hline $\begin{array}{l}\text { Tropical } \\
\text { conditions }\end{array}$ & Wet and hot climate & Intensive bioturbation & & \\
\hline & & & \multicolumn{3}{|l|}{} \\
\hline $\begin{array}{l}\text { Post-depositional } \\
\text { processes }\end{array}$ & $\begin{array}{l}\text { Degradation of organic } \\
\text { matter }\end{array}$ & $\begin{array}{l}\text { Disturbance to the } \\
\text { sedimentary sequence }\end{array}$ & $\begin{array}{l}\text { Complete dissolutions } \\
\text { of carbonates }\end{array}$ & $\begin{array}{l}\text { Preservation of } \\
\text { charcoal and phytoliths }\end{array}$ & \\
\hline $\begin{array}{l}\text { Archaeological } \\
\text { implications }\end{array}$ & $\begin{array}{l}\text { Rare preservation of } \\
\text { organics }\end{array}$ & No clear layering & $\begin{array}{l}\text { Absence of bones and } \\
\text { wood ash }\end{array}$ & $\begin{array}{l}\text { Preservation of } \\
\text { botanical remains }\end{array}$ & $\begin{array}{l}\text { Elevated concentration } \\
\text { of } \mathrm{P}, \mathrm{Mg}, \mathrm{Sr}\end{array}$ \\
\hline
\end{tabular}


Table 3. Summary of the various proxies for the investigation of fire residues and their confidence.

\begin{tabular}{|l|l|l|l|l|}
\hline $\begin{array}{l}\text { Analytical } \\
\text { method }\end{array}$ & Proxy & Data & Embedded information & $\begin{array}{l}\text { Confidence } \\
\text { level }\end{array}$ \\
\hline Microscopy & Micromorphology & Identification of deposition patterns & In situ combustion features or secondary deposition & High \\
\cline { 2 - 5 } & Charcoal & Botanical identification & Type of fuel & High \\
\cline { 2 - 5 } & Ash & Quantification of wood ash pseudomorphs & Type of fuel and intensity and nature of combustion & High \\
& & & Taxonomy and signs for burning & Type of fuel \\
\cline { 2 - 5 } & Phytolith & Pyrogenic alteration of clays, calcite and bones & Estimation of burning temperatures & Moderate \\
\hline Spectroscopy & Minerals & Elevated concentrations of Ca, Sr, P, Mg, K & Identification of anthropogenic markers \\
\cline { 2 - 5 } & Chemicals & & \\
\hline
\end{tabular}

